\title{
Spinal Cord Injury Alters Spinal Shox2 Interneurons by Enhancing Excitatory Synaptic Input and Serotonergic Modulation While Maintaining Intrinsic Properties in Mouse
}

\author{
D. Leonardo Garcia-Ramirez, Ngoc T. Ha, Steve Bibu, Nicholas J. Stachowski, and Kimberly J. Dougherty \\ Marion Murray Spinal Cord Research Center, Department of Neurobiology and Anatomy, Drexel University College of Medicine, Philadelphia, \\ Pennsylvania 19129
}

Neural circuitry generating locomotor rhythm and pattern is located in the spinal cord. Most spinal cord injuries (SCIs) occur above the level of spinal locomotor neurons; therefore, these circuits are a target for improving motor function after SCI. Despite being relatively intact below the injury, locomotor circuitry undergoes substantial plasticity with the loss of descending control. Information regarding cell type-specific plasticity within locomotor circuits is limited. Shox 2 interneurons (INs) have been linked to locomotor rhythm generation and patterning, making them a potential therapeutic target for the restoration of locomotion after SCI. The goal of the present study was to identify SCI-induced plasticity at the level of Shox2 INs in a complete thoracic transection model in adult male and female mice. Whole-cell patch-clamp recordings of Shox2 INs revealed minimal changes in intrinsic excitability properties after SCI. However, afferent stimulation resulted in mixed excitatory and inhibitory input to Shox 2 INs in uninjured mice which became predominantly excitatory after SCI. Shox 2 INs were differentially modulated by serotonin (5-HT) in a concentration-dependent manner in uninjured conditions but following SCI, 5-HT predominantly depolarized Shox2 INs. 5-HT 7 receptors mediated excitatory effects on Shox2 INs from both uninjured and SCI mice, but activation of $5-\mathrm{HT}_{2 \mathrm{~B} / 2 \mathrm{C}}$ receptors enhanced excitability of Shox2 INs only after SCI. Overall, SCI alters sensory afferent input pathways to Shox2 INs and 5-HT modulation of Shox2 INs to enhance excitatory responses. Our findings provide relevant information regarding the locomotor circuitry response to SCI that could benefit strategies to improve locomotion after SCI.

Key words: afferent input; locomotion; plasticity; rhythm generation; serotonin; spinal cord injury

\section{Significance Statement}

Current therapies to gain locomotor control after spinal cord injury (SCI) target spinal locomotor circuitry. Improvements in therapeutic strategies will require a better understanding of the SCI-induced plasticity within specific locomotor elements and their controllers, including sensory afferents and serotonergic modulation. Here, we demonstrate that excitability and intrinsic properties of Shox2 interneurons, which contribute to the generation of the locomotor rhythm and pattering, remain intact after SCI. However, SCI induces plasticity in both sensory afferent pathways and serotonergic modulation, enhancing the activation and excitation of Shox2 interneurons. Our findings will impact future strategies looking to harness these changes with the ultimate goal of restoring functional locomotion after SCI.

Received June 22, 2020; revised May 3, 2021; accepted May 5, 2021.

Author contributions: D.L.G.-R. and K.J.D. designed research; D.L.G.-R., N.T.H., S.B., N.J.S., and K.J.D. performed research; D.L.G.-R., N.T.H., S.B., N.J.S., and K.J.D. analyzed data; D.L.G.-R., N.T.H., S.B., N.J.S., and K.J.D. edited the paper; D.L.G.-R. and K.J.D. wrote the paper.

This work was supported by Wings for Life, National Institutes of Health National Institute of Neurological Disorders and Stroke R01 NS095366, and R01 NS104194 to K.J.D. We thank Lihua Yao and Vlad Zhukarev for technical assistance; members of the Marion Murray Spinal Cord Research Center for discussions related to the work; Rodrigo España for consultations on statistics; and Shayna Singh for comments on the manuscript.

The authors declare no competing financial interests.

Correspondence should be addressed to Kimberly J. Dougherty at kjd86@drexel.edu.

https://doi.org/10.1523/JNEUROSCI.1576-20.2021

Copyright $\odot 2021$ the authors

\section{Introduction}

Spinal cord injury (SCI) compromises descending control of spinal circuits below the lesion, often resulting in locomotor impairments. Rehabilitation relies on the activity of spinal central pattern generators (CPGs) that are capable of autonomously producing the rhythmic, patterned activation of motor neurons and muscles necessary for movement (Graham Brown, 1911). The locomotor CPG is located below the level of most injuries and remains relatively intact following SCI (Bussel et al., 1988; Kjaerulff and Kiehn, 1996; Kremer and Lev-Tov, 1997); however, 
Table 1. Comparison of Shox2 in properties from naive and sham uninjured mice

\begin{tabular}{|c|c|c|c|c|}
\hline & Naive uninjured (mean $\pm S D$ ) & Sham uninjured (mean $\pm S D$ ) & Mann-Whitney $U$ test or unpaired $t$ test & $p^{*}$ \\
\hline Membrane potential (mV) & $-48.9 \pm 5$ & $-46.6 \pm 5$ & $t_{(62)}=1.4$ & 0.1 \\
\hline Input resistance $(\mathrm{M} \Omega$ ) & $731.6 \pm 372$ & $742.2 \pm 485$ & $U=372$ & 0.8 \\
\hline Capacitance (pF) & $47.7 \pm 20$ & $52.9 \pm 27$ & $U=372$ & 0.7 \\
\hline Rheobase current (pA) & $23.4 \pm 12$ & $24.2 \pm 17$ & $U=356$ & 0.6 \\
\hline Voltage threshold (mV) & $-36.9 \pm 4$ & $-35.6 \pm 3$ & $U=369$ & 0.1 \\
\hline AP half-width (ms) & $1.1 \pm 0.4$ & $0.9 \pm 0.3$ & $U=272$ & 0.1 \\
\hline
\end{tabular}

${ }^{*} p<0.05$, statistical significance.

access to the CPG becomes limited. After SCI, sensory afferent fibers which normally interact with the CPG to initiate and adapt ongoing locomotion (McCrea, 2001; Rossignol et al., 2006; Hultborn and Nielsen, 2007; Pearson, 2008; Akay et al., 2014) can be activated by mechanosensory feedback or electrical stimulation (Cote et al., 2017; Formento et al., 2018; Taccola et al., 2018). Additionally, pharmacological manipulation of the receptors present on spinal neurons within the CPG can induce and enhance motor outcomes, particularly when combined with training and/ or electrical stimulation (Gerasimenko et al., 2007; Courtine et al., 2009; Guertin, 2009). These strategies have largely focused on activating locomotor circuits as a whole, but current understanding of spinal circuit organization allows for more precise neuronal population targeting.

To achieve control of locomotor-related populations after SCI, an understanding of both locomotor neuronal organization and SCI-induced alterations is required. Plasticity after SCI is evident at the molecular, cellular, and circuit levels (Edgerton et al., 2004; Rossignol et al., 2008; Vinay et al., 2008). Changes to motor neurons have been studied in great detail, where plasticity includes alterations in membrane properties, dendritic spine densities, persistent inward currents which mediate plateau potentials, and sensitivity to serotonin (5-HT) (Bennett et al., 2001a; Fouad et al., 2010; Bandaru et al., 2015). Advances in genetics have established the identity and function of several locomotor-related interneuron (IN) populations (Goulding, 2009; Kiehn, 2016). Despite this, cell type-specific plasticity and the roles of IN populations in dysfunction and recovery after SCI have only recently begun to be explored (Bui et al., 2016; Lin et al., 2019). Changes to ion channel expression and excitability have been observed in subpopulations of sensory processing INs within the dorsal horn (Dougherty and Hochman, 2008; Rank et al., 2015). However, intrinsic properties of locomotor-related V2a INs remain unchanged after SCI but similar to motor neurons, V2a INs display supersensitivity to 5-HT after SCI (Husch et al., 2012). To date, V2a INs are the only locomotor-related population to be examined in this manner.

Shox2 INs are of particular interest in the context of SCI as they are involved in rhythm generation, locomotor patterning, and receive low threshold inputs via excitatory and inhibitory pathways (Dougherty et al., 2013; Ha and Dougherty, 2018; Li et al., 2019). Whereas these previous studies of Shox 2 INs were restricted to neonatal preparations, the goal of the present study was to determine the SCI-induced plasticity that occurs at the level of adult Shox2 INs in terms of intrinsic and excitability properties, serotonergic modulation, and sensory afferent control. We found that Shox2 INs in adult mouse lumbar spinal cord receive synaptic inputs mediated by both excitatory and inhibitory sensory afferent pathways. Further, 5-HT modulates Shox2 INs in a concentration-dependent manner, either reducing or enhancing excitability with activation of $5-\mathrm{HT}_{7}$ receptors increasing cellular excitability. Following a chronic thoracic spinal transection, intrinsic properties of Shox 2 INs do not change. However, plasticity is evident within afferent pathways to Shox2 INs and 5-HT neuromodulation of Shox2 INs specifically involving $5-\mathrm{HT}_{2 \mathrm{~B} / 2 \mathrm{C}}$ receptors, favoring excitation. The lack of intrinsic plasticity after chronic SCI suggests independence of CPG neurons from descending control to perform locomotor functions. However, changes at the levels of afferent and neuromodulatory control will affect therapeutic strategies targeting these access points to Shox2 INs to improve locomotor function. The present work exposes important circuitry modifications to serve as an entry point for future research aimed at improving SCI therapies.

\section{Materials and Methods}

Mouse lines and experimental groups. Experiments were performed using the Shox2::Cre; Rosa26-flox-Stop-flox-tdTomato (Ai9 from Jax mice, \#007909) transgenic mice (Madisen et al., 2010; Dougherty et al., 2013). All experimental procedures followed National Institutes of Health guidelines and were approved by the Institutional Animal Care and Use Committee at Drexel University.

The experiments were performed in three different treatment conditions: (1) mice without any surgical procedure (control mice $n=43$ ), (2) mice with identical surgical conditions to the SCI group (see below) but without transection of the spinal cord (sham mice, $n=11$ ), and (3) mice with complete spinal transection surgery (SCI mice, $n=35$ ). Shox 2 INs from control and sham groups did not show differences in the properties measured (Table 1); therefore, we considered them as a single group (uninjured mice).

SCI surgery. Male and female mice (6-10 weeks old) were anesthetized with isoflurane ( $4 \%$ induction, $2 \%$ maintenance). Dorsal skin was shaved and sterilized with betadine and isopropyl alcohol. Incision was performed from the thoracic to lumbar vertebral segments. Following laminectomy, approximately one segment of spinal cord was removed, resulting in a complete transection of the thoracic spinal cord at T8-T10. In sham mice, the laminectomy was performed with no transection of the spinal cord. Buprenorphine SR $(0.5 \mathrm{mg} /$ $\mathrm{kg}$ ) and either ampicillin $(20 \mathrm{mg} / \mathrm{kg})$ or Baytril $(10 \mathrm{mg} / \mathrm{kg})$ were administrated subcutaneously perisurgically. Mice were monitored and bladders were expressed manually twice daily. Spinal transected mice were incapable of weight supported stepping and dragged their hindlimbs. Terminal electrophysiology or immunocytochemistry experiment occurred 6-10 weeks after transection. At the terminal experiment, we visually inspected the lesion site to verify the completeness of the transection. In cases where lesions were observed to be incomplete $(n=5)$, the data were excluded from analysis.

Immunohistochemistry. At the terminal experiment, 3 uninjured and 3 SCI mice were anesthetized with ketamine $(150 \mathrm{mg} / \mathrm{kg})$ and xylazine $(15 \mathrm{mg} / \mathrm{kg})$ and perfused transcardially with $50 \mathrm{ml}$ of $0.1 \mathrm{M}$ PBS, followed by $50 \mathrm{ml}$ of $4 \%$ PFA in PBS. Spinal cords were then harvested from each animal and fixed in 4\% PFA solution for 2-3 h at room temperature. Fixed spinal cords were subsequently maintained in $30 \%$ sucrose in PBS for at least $24 \mathrm{~h}$. Tissue was then blocked in OCT compound (Thermo 
Fisher Scientific) over dry ice and stored at $-80^{\circ}$. Spinal cords were sectioned $(25 \mu \mathrm{m})$ transversely on a cryostat (Microm HM $505 \mathrm{E}$ ) and directly mounted onto slides. For immunohistochemistry, slides were washed in $0.1 \mathrm{M}$ PBS solution for $10 \mathrm{~min}(3 \times)$ before being bathed in blocking solution containing $2.5 \mathrm{ml}$ of donkey serum, $50 \mathrm{ml}$ of $0.1 \mathrm{M}$ PBS, $0.8 \mathrm{ml}$ of $0.3 \%$ Triton X-100 solution. Slides were incubated in rabbit anti-5-HT primary antibody (1:20,000, ImmunoStar) overnight at $4^{\circ}$ $\mathrm{C}$ and AlexaFluor-405 goat anti-rabbit IgG (1:400, Invitrogen) for 3-4 h, before being coverslipped using Fluoromount-G (Thermo Fisher Scientific). Images were acquired as sequential $z$ stacks using a confocal microscope (Leica Microsystems SP8). Images were focused with a $10 \times$ objective on the regions most populated with labeled Shox2 (laminae VII) from spinal cord hemisections, sections of $206 \times 206$ pixels were analyzed with custom-written MATLAB (The MathWorks) script.

Spinal cord preparations. For terminal electrophysiology experiments, 10- to 16-week-old uninjured, sham, and transected (SCI) mice were anesthetized with ketamine $(150 \mathrm{mg} / \mathrm{kg})$ and xylazine $(15 \mathrm{mg} / \mathrm{kg})$, decapitated, and eviscerated. Spinal cords were then removed in ice-cold dissecting solution containing the following (in $\mathrm{mm}$ ): 222 glycerol, 3 $\mathrm{KCl}, 11$ glucose, $25 \mathrm{NaHCO}_{3}, 1.3 \mathrm{MgSO}_{4}, 1.1 \mathrm{KH}_{2} \mathrm{PO}_{4}$, and $2.5 \mathrm{CaCl}_{2}$ and gassed with $95 \% \mathrm{O}_{2}$ and $5 \% \mathrm{CO}_{2}$ (Husch et al., 2012). The lumbar spinal cord (L2-5) was sectioned transversely or parasagittally (300-350 $\mu \mathrm{m}$ ) with dorsal roots attached (see Fig. $4 A$ ) using a vibrating microtome (Leica Microsystems). Slices were next transferred to ACSF, containing the following (in $\mathrm{mm}$ ): $111 \mathrm{NaCl}, 3 \mathrm{KCl}, 11$ glucose, $25 \mathrm{NaHCO}_{3}, 1.3$ $\mathrm{MgSO}_{4}, 1.1 \mathrm{KH}_{2} \mathrm{PO}_{4}$, and $2.5 \mathrm{CaCl}_{2}$ at $37^{\circ} \mathrm{C}$ for $30 \mathrm{~min}$ and then passively equilibrated to room temperature for another $30 \mathrm{~min}$ before recording. Dissecting and recording solutions were continuously aerated with $95 \% / 5 \% \mathrm{O}_{2} / \mathrm{CO}_{2}$.

Patch-clamp recordings. All recordings were performed at room temperature. Fluorescently labeled (tdTomato) Shox2 INs were visualized with a $63 \times$ objective lens on a BX51WI scope (Olympus) using LED illumination (Andor Mosaic System). Patch electrodes were pulled to tip resistances of 5-8 $\mathrm{M} \Omega$ using a multistage puller (Sutter Instruments) and were filled with intracellular solution, which contained the following (in mM): 128 K-gluconate, 10 HEPES, $0.0001 \mathrm{CaCl}_{2}, 1$ glucose, $4 \mathrm{NaCl}, 5$ ATP, and 0.3 GTP. Data were collected with a Multiclamp 700B amplifier (Molecular Devices) and Clampex software (pClamp9, Molecular Devices). Signals were digitized at $20 \mathrm{kHz}$ and filtered at $4 \mathrm{kHz}$. Glass suction electrodes were used to stimulate dorsal roots as distally as possible. The electrical stimulation was delivered at $0.1 \mathrm{~Hz}$ frequency with $0.25 \mathrm{~ms}$ pulse duration at $100-500 \mu \mathrm{A}$ or $1-10$ times the threshold intensity that recruited the most excitable afferent fibers $(\mathrm{xT})$ in the dorsal root. Afferent volleys were recorded with glass suction electrodes at the most proximal segment of dorsal roots (signal bandpass filtered 1-1000 Hz; gain 1000).

Pharmacology. Stock solutions of drugs (1-10 mM) were made and stored at $-20^{\circ} \mathrm{C}$ until needed and then diluted in normal ACSF to experimental concentration. SB206553 and ketanserin were dissolved in DMSO and resulted in a final DMSO concentration of $0.02 \%$ in the bath. In subsets of experiments, serotonin (5-HT, 0.01-100 $\mu \mathrm{M})$, strychnine (10 $\mu \mathrm{M})$, and/or bicuculline $(10 \mu \mathrm{M})$ were bath-applied for 8-15 min each, depending on the protocol. Cumulative dose-response curves for 5-HT were generated at concentrations of $0.01,0.1,1,10$, and $100 \mu \mathrm{M}$. In experiments elucidating the participation of specific 5-HT receptor subtypes, measurements were done in three conditions: regular ACSF, 8-10 min after the application of the 5-HT antagonists SB206553 (1 $\mu \mathrm{M})$, ketanserin $(1 \mu \mathrm{M})$, or WAY-100635 $(10 \mu \mathrm{M})$, and 8-10 after a subsequent application of the agonist DOI $(10 \mu \mathrm{M})$ or $8-\mathrm{OH}-\mathrm{DPAT}(10$ $\mu \mathrm{M})$. All drugs were purchased from Sigma Millipore.

Experimental design and statistical analyses. Data analysis was performed with Clampfit (Molecular Devices) and MATLAB (The MathWorks). Statistical tests and post hoc analyses used are stated for each experiment and performed with GraphPad Prism (GraphPad Software). All results were presented as mean $\pm \mathrm{SD}$, unless otherwise stated. Statistical significance was set at $p<0.05$. The distribution of the data was determined by Shapiro-Wilk normality test. The statistical analysis used depended on the test for normal distribution and the experimental conditions. In the case of normally distributed data, we performed paired $t$ tests (comparison between before and after drug conditions), one-sample $t$ tests (comparison between $\%$ of control or deltas), unpaired $t$ tests (comparison between uninjured and SCI conditions), repeated-measures one-way ANOVAs with Bonferroni's post hoc test (comparison for the effects of $\geq 3$ concentrations), and two-way ANOVAs with Bonferroni's post hoc test (comparison between uninjured and SCI for the effects of $\geq 3$ concentrations). In the cases where data were not normally distributed, we performed Wilcoxon matched pairs test (comparison between before and after drug conditions), Wilcoxon signed rank test (comparison between \% of control or deltas), Mann-Whitney test (comparison between uninjured and SCI conditions), Friedman with Dunn's post hoc test for matched data (comparison for the effects of $\geq 3$ concentrations), and Kruskal-Wallis with Dunn's post hoc test for nonmatched data (comparison for the effects of $\geq 3$ conditions between uninjured and SCI). In the experiments considering fraction of total data, we performed binomial tests (for two conditions) and $\chi^{2}$ tests (for more than two conditions). The detailed statistical analysis for each experiment is reported in Results, figure legends, and tables.

\section{Results}

\section{Shox 2 INs in the adult mouse}

Shox2 INs are part of the locomotor CPG (Dougherty et al., 2013). Recordings from Shox 2 INs to date have been primarily in neonatal and young mouse preparations (Dougherty et al., 2013; Ha and Dougherty, 2018; Li et al., 2019). Therefore, we first sought to determine the firing and cellular properties of Shox2 INs in adult mice. Fluorescent neurons in lumbar sections of Shox2::Cre; lsl-tdTomato adult mice have a similar distribution (Fig. 1A) to that reported in neonates (Dougherty et al., 2013), with cells primarily located throughout lamina VII. Labeling of afferent fibers that express Shox 2 is prominent, particularly in the dorsal horn. We performed whole-cell patch-clamp recordings from visually identified Shox 2 INs in spinal cord slices from adult mice. The majority of Shox 2 INs in adult spinal cord displayed a tonic firing activity during step depolarizing currents (Fig. 1Ci; 56 of 75 neurons). The remaining neurons fired either with initial burst (Fig. 1Cii; 7 of 75) or with a delay (Fig. 1Ciii; 12 of 75). The mean threshold for the generation of an action potential was $-36.6 \pm 4 \mathrm{mV}$ ( $n=64$ neurons). All neurons displayed afterhyperpolarization with amplitude average of $13.9 \pm 3 \mathrm{mV}$ $(n=64)$. These recordings show that Shox2 INs display one of three firing properties, with most firing tonically throughout the current step adult mouse lumbar spinal cord.

\section{Minimal changes in Shox2 in properties following SCI}

Cellular plasticity after SCI has been observed in unidentified spinal INs and motor neurons located below the injury, affecting their excitability (Bennett et al., 2001b; Boulenguez et al., 2010; Bellardita et al., 2017). However, there is a rich interneuronal diversity in the spinal cord and cell type-specific plasticity is only beginning to be identified (Dougherty and Hochman, 2008; Husch et al., 2012). To identify chronic SCI-induced plasticity in the intrinsic and excitability properties of Shox 2 INs, we performed a complete transection at T8/T9 spinal levels in mice, 6-10 weeks before experiments (Fig. $2 A$ ). To corroborate the disruption of the supraspinal tracts to the spinal cord, we performed immunohistochemistry with an antibody to 5-HT to label the serotonergic axons in the lumbar cord and compared the presence of 5-HT descending axons in the uninjured and SCI mice (Fig. 2B). The lumbar cord was devoid of 5-HT axon labeling in sections from SCI mice (Fig. 2C), further supporting a lack of supraspinal connections to the lumbar spinal cord. The number of Shox2 neurons in sections from lumbar segments was not 
modified in complete spinal transected mice (Fig. 2D; $31.3 \pm 5$ and $35.3 \pm 4$ Shox2 INs per hemisection in 3 uninjured and SCI mice, respectively, MannWhitney test, $U=3.0, p=0.7$ ), suggesting that Shox2 IN survival is not affected after SCI.

We measured the intrinsic properties of Shox2 INs from both uninjured $(n=64)$ and SCI $(n=47)$ mice. We did not find differences in the resting membrane potential (uninjured: $-48.4 \pm$ $5 \mathrm{mV}$; SCI: $-47.8 \pm 5 \mathrm{mV}$, MannWhitney test, $U=1402, p=0.54$; Fig. $3 A$ ), input resistance (uninjured: $734.0 \pm$ $396 \mathrm{M} \Omega$; SCI: $737.4 \pm 341 \mathrm{M} \Omega$, MannWhitney test, $U=1498, p=0.7$; Fig. $3 B$ ), and rheobase current (uninjured: $23.6 \pm 13 \mathrm{pA}$; SCI: $27.5 \pm 14 \mathrm{pA}$, Mann-Whitney test, $U=1309, p=0.08$; Fig. 3C) of Shox2 INs between the two groups. Additionally, we found no significant difference in the whole-cell capacitance $\left(\mathrm{C}_{\mathrm{m}}\right)$, membrane time constant, action potential half-width, and after hyperpolarization amplitude of Shox 2 INs between uninjured and SCI mice (Table

2). However, we found a slightly more depolarized voltage threshold to generate action potentials in the SCI group (uninjured: $-36.6 \pm 4 \mathrm{mV}$; SCI: $-34.8 \pm 4 \mathrm{mV}$, unpaired $t$ test, $t_{(110)}=2.1$, $p=0.03$; Fig. $3 D$ ). To determine whether the modest increase in the threshold to produce action potentials affects the firing frequency of Shox2 INs after SCI, we injected depolarizing current steps in these neurons (Fig. 3E) and found that the number of spikes evoked by a $1 \mathrm{~s}$ injection of current increased linearly with the current in both cases (Fig. $3 F$ ) with no changes in the slope of the fit linear regression (uninjured: $0.35 \pm 0.02 \mathrm{~Hz} / \mathrm{pA}, n=17$; SCI: $0.38 \pm 0.02 \mathrm{~Hz} / \mathrm{pA}$, $n=20)$. We observed a reduction in the incidence of tonic firing Shox2 INs and an increased incidence of initial bursting Shox2 INs from SCI mice (tonic firing, initial bursting, and delay firing for uninjured: $74.6 \%, 9.3 \%$, and $16 \%$ and for SCI: $63.9 \%, 19.6 \%$, and $16.3 \%$, respectively, $\chi^{2}$ test, $\chi_{(2)}^{2}=3.06, p=0.01$; Fig. $\left.3 G\right)$. Interestingly, a subset of Shox2 INs from both uninjured and SCI mice spontaneously oscillate at resting, or more depolarized, membrane potentials (Fig. $3 H$, uninjured: $27 \%, 8 / 29$, black trace; SCI: $19 \%, 6 / 31$, red trace). Together, these data show that chronic SCI does not alter the majority of the properties related to excitability of Shox2 INs.

\section{SCI induces plasticity in sensory afferent pathways to Shox2 INs}

Locomotor CPG networks are strongly modulated by sensory afferent feedback, which allows for the adaptation of locomotion to the environmental conditions (Rossignol et al., 2006; Hultborn and Nielsen, 2007). Afferent feedback is particularly important after SCI since the lack of supraspinal inputs to CPGs leaves afferent fibers as the principal source of input to activate locomotor networks (Edgerton et al., 2008; Rossignol and Frigon, 2011; Wagner et al., 2018). Indeed, abolishing proprioceptive and mechanoreceptive afferent feedback and silencing sensory relay INs impairs locomotor recovery (Bouyer and Rossignol, 2003; Takeoka et al., 2014; Bui et al., 2016). To elucidate the sensory afferent pathways to Shox2 INs and to
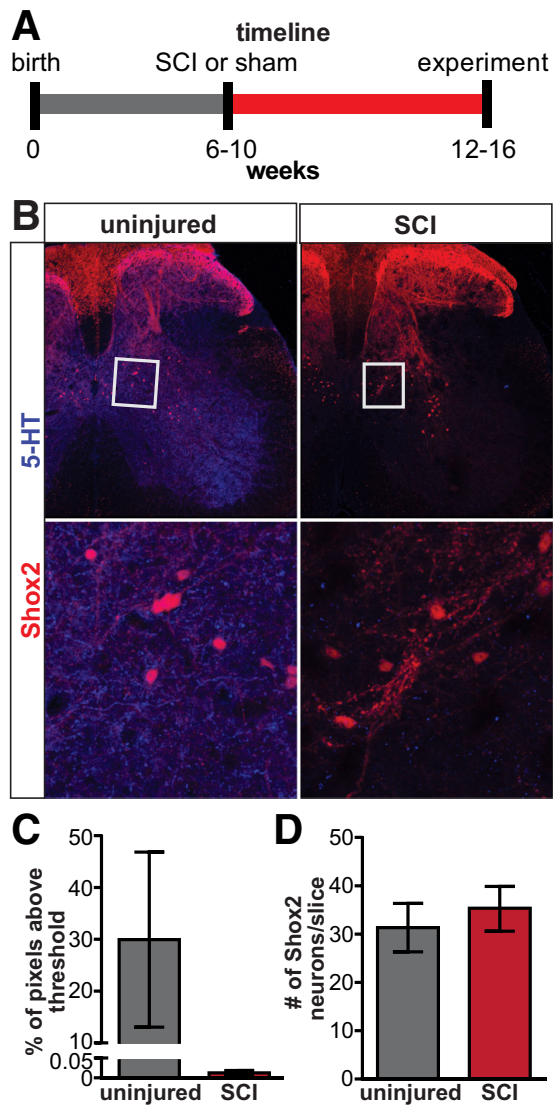

Figure 2. Timeline and histology after $\mathrm{SCl}$ A, Experimental timeline of sham and $\mathrm{SCl}$ mice. $\boldsymbol{B}$, Immunoreactivity of 5-HT (blue) in transverse sections from uninjured (left) and SCl (right) Shox2:: Cre; Isl-tdTomato mice. Bottom panels, Higher magnification of boxed region on top panels. C, Mean pixels above threshold for 5-HT immunoreactivity from uninjured (gray bar) and SCl (red bar) sections. D, Mean number of Shox2 neurons per side in slices from uninjured (gray bar) and SCI (red bar) mice. Data are mean \pm SD. 


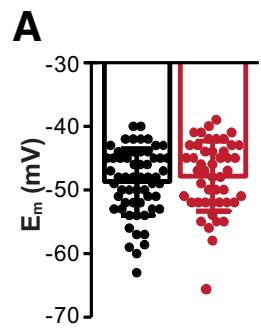

B

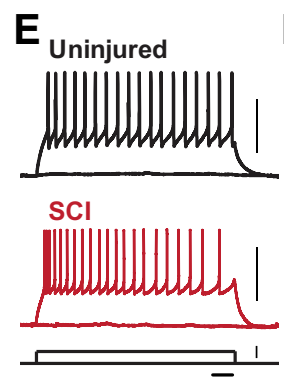

$\mathbf{F}$
B
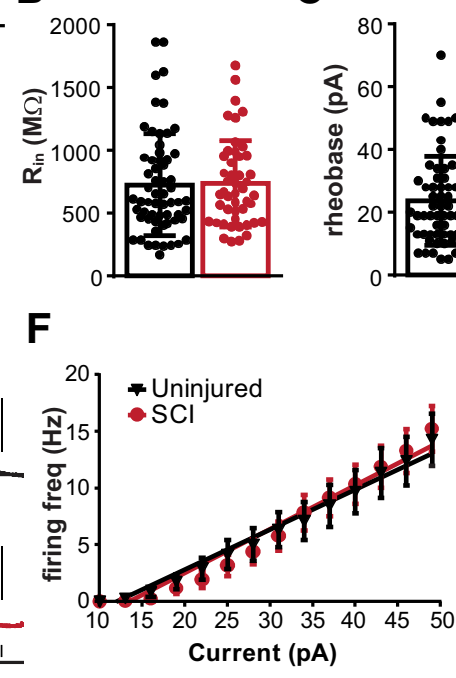

C

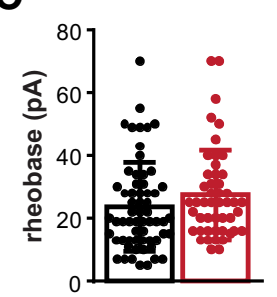

D
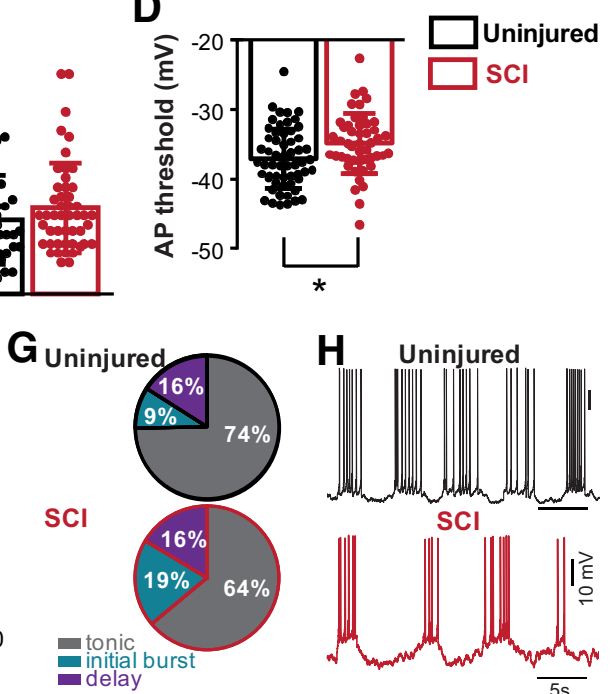

Figure 3. Shox2 IN intrinsic and firing properties from uninjured and SCI mice. A-D, Comparisons of intrinsic properties of Shox2 INs from uninjured (black bars) and SCI (red bars). There were no significant differences in $(\boldsymbol{A})$ membrane potential $\left(E_{m}\right),(\boldsymbol{B})$ input resistance $\left(R_{\text {in }}\right)$, or $(\boldsymbol{C})$ rheobase current. $\boldsymbol{D}$, Action potential threshold was significantly more depolarized in Shox2 INs from SCI mice (unpaired $t$ test, $p=0.03$ ). Dots represent individual data points. Bar graphs represent mean $\pm S D$. $E$, Examples of Shox2 IN responses to a $50 \mathrm{pA}$ depolarizing current from uninjured (black trace) and SCI (red trace) mice. $\boldsymbol{F}$, Mean firing frequency/current response and linear fit for uninjured (black) and SCI (red). $\mathbf{G}$, Pie charts represent incidence of Shox2 IN firing types from uninjured (top) and SCI (bottom) mice. Gray represents tonic firing. Teal represents initial burst firing. Purple represents delay firing. $\boldsymbol{H}$, Examples of Shox2 INs from uninjured (black) and $\mathrm{SCI}$ (red) mice spontaneously oscillating in control recoding solution.

Table 2. Comparison of Shox2 IN properties from uninjured and SCI mice

\begin{tabular}{|c|c|c|c|c|}
\hline & Uninjured (mean \pm SD) & $\mathrm{SCl}$ (mean $\pm \mathrm{SD}$ ) & Mann-Whitney $U$ or unpaired $t$ test & $p$ \\
\hline Membrane potential (mV) & $-48.4 \pm 5$ & $-47.8 \pm 5$ & $U=1402$ & 0.54 \\
\hline Input resistance $(\mathrm{M} \Omega$ ) & $734.0 \pm 396$ & $737.4 \pm 341$ & $U=1498$ & 0.7 \\
\hline Capacitance (pF) & $48.9 \pm 21$ & $40.3 \pm 15$ & $U=1392$ & 0.05 \\
\hline Rheobase current (pA) & $23.6 \pm 13$ & $27.5 \pm 14$ & $U=1309$ & 0.08 \\
\hline F/l slope (Hz/pA) & $0.35 \pm 0.02$ & $0.38 \pm 0.02$ & & \\
\hline AP threshold (mV) & $-36.6 \pm 4$ & $-34.8 \pm 4$ & $t_{(110)}=2.1$ & $0.03^{*}$ \\
\hline sEPSP frequency (Hz) & $1.3 \pm 0.3$ & $1.4 \pm 0.5$ & $U=32$ & 0.7 \\
\hline sEPSP amplitude (mV) & $0.6 \pm 0.1$ & $1.1 \pm 0.2$ & $t_{(15)}=4.3$ & $0.0006^{*}$ \\
\hline sIPSP frequency $(\mathrm{Hz})$ & $0.6 \pm 0.2$ & $0.5 \pm 0.2$ & $U=31$ & 0.7 \\
\hline sIPSP amplitude (mV) & $0.5 \pm 0.1$ & $0.9 \pm 0.2$ & $t_{(15)}=4.4$ & $0.0005^{*}$ \\
\hline
\end{tabular}

* Statistical significance: $p<0.05$

determine whether changes occur in these pathways after SCI, we used transverse (Fig. 4A) and sagittal (Fig. 4B) adult spinal slice preparations with intact dorsal roots, to stimulate afferent fibers while performing whole-cell patch-clamp recordings from Shox2 INs.

In order to determine the possible afferent fiber types stimulated in this preparation, we performed a set of experiments where we stimulated the distal portion of a dorsal root while recording the resulting afferent volley in the proximal segment of the dorsal root attached to an adult slice. The stimulation strengths were classified as a function of a threshold (T) to activate the most excitable fibers (Fig. $4 C$ ). We correlated the volley thresholds with the stimulation current applied to the root (Fig. $4 D$ ). We found the threshold ranged from 13-80 $\mu \mathrm{A}$ (mean = $38.8 \pm 29 \mu \mathrm{A}, n=8)$.

We recorded postsynaptic potentials and currents in Shox2 INs evoked by dorsal root stimulation. The percentage of Shox 2 INs receiving monosynaptic or polysynaptic sensory input was similarly low in both uninjured and SCI mice, 12\% (19 of 160) and $17 \%$ (22 of 127), respectively (binomial $t$ test two-tailed, $p=0.07$ ). This is likely to be a substantial underestimate given the slicing procedure, which likely results in damage to some of the afferent fibers projecting into the cord. Only Shox2 INs, which responded to stimuli were considered for this section. We considered Shox 2 INs displaying postsynaptic potentials at stimulation strengths of $\leq 100 \mu \mathrm{A}$ (corresponding to $\sim 2.5 \mathrm{~T}$ ) to be receiving low threshold afferent input and Shox2 INs responding to stimuli $>100 \mu \mathrm{A}$ to be receiving high threshold afferent input. All Shox2 INs that responded to low threshold stimuli also responded to higher threshold stimuli. We found that the percentage of Shox2 INs receiving low and high threshold afferent inputs was the same between uninjured mice (24\%, 4 of 17 received low threshold and 76\%, 13 of 17 high threshold) and SCI mice (24\%, 5 of 21 received low threshold and 76\%, 16 of 21 high threshold, binomial $t$ test two-tailed, $p>0.9$; Fig. $4 E$ ). The limitations of the slice preparation, such as proximity of the stimulus electrode to the cord, size of the roots, and slice/root integrity, make it difficult to measure latency accurately. Trial-to-trial 
jitter and failures were evident in the majority of the responses evoked by dorsal root stimulation (uninjured: 12 of 17; SCI: 13 of 19; Fig. 4F,G), suggesting that Shox 2 INs primarily receive sensory afferent input via polysynaptic pathways. However, the possibility that some are monosynaptic cannot be ruled out. These data demonstrate that electrical stimulation of dorsal roots produces synaptic inputs to Shox2 INs via predominantly polysynaptic pathways in similar proportions for uninjured and SCI mice.

To determine the type of sensory afferent input individual Shox2 INs received, we recorded the postsynaptic responses at resting membrane potential and classified Shox2 INs as receiving excitatory (Fig. 5A) or inhibitory input (Fig. $5 B$ ). Some of the Shox2 INs receiving inhibitory inputs were observed to have obvious excitatory components at rest. Shox2 INs receiving inhibitory inputs were further subdivided into exclusively inhibitory (Fig. 5Bi) or mixed excitatory and inhibitory (Fig. 5Bii) input based on evoked postsynaptic potentials or currents at different membrane potentials (Fig. 5Bi) or after fast inhibitory transmission blockade with bicuculline and strychnine (Fig. 5Bii); $43 \%$ (6 of 14) of the Shox 2 INs from uninjured mice responded to afferent stimulation with EPSPs; 57\% (8 of 14) responded with IPSPs, and were further subdivided into exclusively inhibitory $(21 \%, 3$ of 14$)$ or mixed excitatory and inhibitory (33\%, 5 of 14; Fig. 5C). After SCI, only 1 Shox 2 IN tested received detectable IPSPs at rest. The remaining Shox2 INs received EPSPs in response to afferent stimulation (93\%, 13 of 14; Fig. $5 C$, bottom). These data suggest that Shox2 INs received sensory afferent input mediated by both excitatory and inhibitory pathways; and after SCI, there is a significant $\left(\chi_{(2)}^{2}=14.5, p=0.0007\right)$ imbalance in these pathways enhancing the excitatory response to sensory afferent transmission.

One possible explanation for the lack of evoked IPSPs in Shox2 neurons after SCI is a change in chloride homeostasis, which may cause GABA or glycine-mediated postsynaptic potentials to appear excitatory because of a depolarization of the chloride reversal potential ( $\mathrm{Lu}$ et al., 2008; Boulenguez et al., 2010). Therefore, we examined spontaneous synaptic inputs to a subset of Shox2 INs from both uninjured $(n=7)$ and SCI mice $(n=10)$ at the same membrane potential at which the evoked responses were recorded ( -50 to $-55 \mathrm{mV}$; Fig. 5D). Shox2 INs showed similar frequencies of both spontaneous excitatory postsynaptic potentials (sEPSPs, $1.3 \pm 0.3 \mathrm{~Hz}$ and $1.4 \pm 0.5 \mathrm{~Hz}$ in uninjured and SCI mice, respectively, Mann-Whitney test, $U=32, p=0.7$; Fig. 5Ei) and spontaneous inhibitory postsynaptic potentials (sIPSPs, $0.6 \pm 0.2 \mathrm{~Hz}$ and $0.5 \pm 0.2 \mathrm{~Hz}$ in uninjured and SCI mice, respectively,
Mann-Whitney test, $U=31, p=0.7$; Fig. 5Ei). However, Shox2 INs from both uninjured and SCI mice received more sEPSPs than sIPSPs (Kruskal-Wallis test, $\mathrm{H}=22.06, p<0.0001$, Dunn's post hoc test, $p=0.02$ in uninjured and $p=0.001$ for SCI; Fig. $5 E i)$. Interestingly, the amplitude of both sEPSPs and sIPSPs is larger in Shox2 INs from SCI mice compared with uninjured mice (sEPSPs: $0.6 \pm 0.1 \mathrm{mV}$ uninjured, $1.1 \pm 0.2 \mathrm{mV}$ SCI, unpaired $t$ test, $t_{(15)}=4.3, p=0.0006$; sIPSPs: $0.5 \pm 0.1 \mathrm{mV}$ uninjured, $0.9 \pm 0.2 \mathrm{mV} \mathrm{SCI}$, unpaired $t$ test, $t_{(15)}=4.4, p=0.0005$; Fig. 5Eii; Table 2). A larger amplitude of the sIPSPs is opposite to the result expected with a more depolarized chloride reversal potential. Although we cannot rule out changes in the chloride reversal potential with these recordings, our data demonstrate that the increase in the sensory afferent excitatory inputs to 


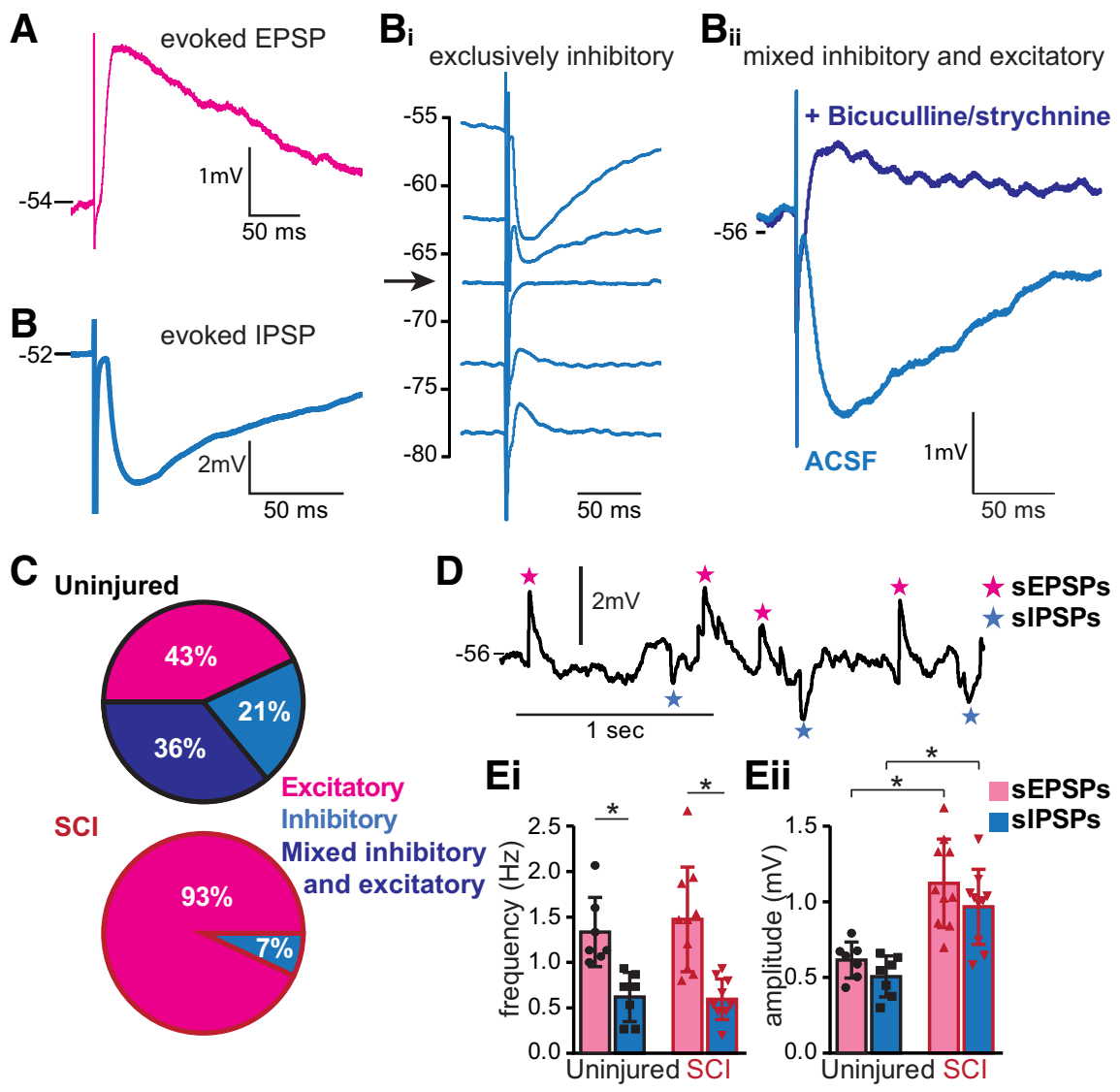

Figure 5. Primary afferent-evoked inputs to Shox2 INs undergo changes following SCl. $\boldsymbol{A}-\boldsymbol{C}$, Classification of Shox2 INs depending on the type of synaptic potentials evoked by the stimulation of dorsal root afferent fibers. $\boldsymbol{A}$, Example of a Shox2 IN receiving an EPSP in response to afferent stimulation. $\boldsymbol{B}$, Example of a Shox2 IN receiving an IPSP in response to dorsal root stimulation. Neurons receiving IPSPs could be divided. Bi, Example of Shox2 IN receiving only inhibitory input, as confirmed by responses at different membrane potentials, including near the IPSP reversal potential (arrow). Bii, Example of a Shox2 IN receiving an excitatory input that is masked by the IPSP. Here, the IPSP is prominent until the EPSP is revealed by application of bicuculline and strychnine. $\boldsymbol{C}$, Incidence of each type of Shox2 IN in uninjured (top) and SCI (bottom). Excitatory (pink), only inhibitory (blue), and mixed excitatory and inhibitory (dark blue). D, sEPSPs (pink stars) and sIPSPs (blue stars) at resting membrane potential of a Shox2 IN from an SCI mouse that displayed only excitatory inputs following afferent stimulation. Ei, Mean frequency of sEPSPs (pink) and sIPSPs (blue) recorded in Shox2 INs from uninjured (left) and SCI (right) mice. ${ }^{*} p<0.05$ (Mann-Whitney test). Eii, Mean amplitude of sEPSPs (pink) and sIPSPs (blue) from Shox2 INs from uninjured (left) and SCI (right) mice. * $p<0.05$ (Kruskal-Wallis test, Dunn's post hoc test).

Shox2 INs is not likely to be caused by changes in the Shox2 IN chloride homeostasis.

\section{5-HT modulates the sensory afferent transmission to Shox2 INs}

Serotonin reduces sensory afferent transmission to motor neurons and dorsal horn INs (Hasegawa and Ono, 1996; Hochman, 2001; Honda et al., 2004; D’Amico et al., 2013; Garcia-Ramirez et al., 2014). However, the serotonergic control of the afferent transmission to specific interneuronal cell types is still unknown. We sought to explore the serotonergic modulation of inputs to Shox 2 INs. To evaluate the serotonergic control of the sensory afferent transmission and how it changes after SCI, we initially brought Shox2 INs to $\sim-70 \mathrm{mV}$ with bias current in current clamp and recorded PSPs evoked by the stimulation of afferent fibers. Following initial recordings, 5-HT (10 $\mu \mathrm{M})$ was applied. 5HT significantly reduced the evoked postsynaptic potential amplitude recorded to $44.3 \pm 23 \%$ of the control $(n=8$, Fig. $6 A$; one-sample $t$ test, $\left.t_{(7)}=6.6, p<0.001\right)$. The PSP amplitude reduction was similar in both uninjured and SCI mice (reduced to $45.3 \pm 29 \%$ and $43.4 \pm 21 \%$ of control, respectively, $n=4$, Mann-Whitney test $U=7.0, p=0.6$; Fig. $6 B$ ). Interestingly, the effects of 5-HT on the amplitude of evoked EPSPs and IPSPs were different. EPSPs recorded in Shox2 INs from uninjured $(n=3)$ and SCI $(n=2)$ mice were reduced to $36.9 \pm 25 \%(n=5)$ in the presence of 5-HT, while IPSP amplitudes were similar in control and 5-HT $(90.8 \pm 9 \%$ of control, $n=3$ uninjured; Fig. $6 C, D)$. Furthermore, input resistance of Shox 2 INs did not significantly change in the presence of 5-HT in both cases (uninjured: $920.1 \pm 412 \mathrm{M} \Omega$ in control to $860.4 \pm 342 \mathrm{M} \Omega$ after $10 \mu \mathrm{M} 5$-HT, $n=13$; and SCI: $576.4 \pm 297 \mathrm{M} \Omega$ in control to $688.9 \pm 377 \mathrm{M} \Omega$ after $10 \mu \mathrm{M} 5-\mathrm{HT}, n=6$, Mann-Whitney test, $U=80, p=0.8$ and $U=15, p=0.6$ for uninjured and SCI, respectively; Fig. $6 E$ ). These results suggest that the 5-HT-mediated reduction in excitatory synaptic transmission is primarily because of actions presynaptic to Shox 2 INs, either at the terminals of the afferent fibers or at the INs in the pathways mediating afferent transmission to Shox2 INs.

\section{Alterations in 5-HT modulation of Shox 2 in after SCI}

The supraspinal control of locomotor networks includes pro-locomotor effects produced by the 5-HT released from the reticulospinal fibers (Jacobs and Fornal, 1993; Hochman, 2001; Madriaga et al., 2004; Jordan et al., 2008). Further, CPG neurons are expected to respond to drugs that induce locomotion, such as 5-HT (MacLean et al., 1995; Madriaga et al., 2004; Dai et al., 2009). However, the cell type-specific effects of 5-HT on CPG INs and how this modulation changes after SCI are only beginning to be explored (Husch et al., 2012). To investigate the 5-HT modulation of Shox2 INs, we performed whole-cell patch-clamp recordings of Shox 2 INs from uninjured and SCI mice and applied 5-HT at different concentrations.

In general, low 5-HT concentrations depressed the activity of Shox2 INs and higher concentrations enhanced the activity of Shox 2 INs from uninjured mice. These effects were also seen in measures of membrane potential, rheobase, and evoked firing frequency. We found that 5 -HT produced a concentration-dependent change in some Shox 2 IN properties (Table 3). At $0.1 \mu \mathrm{M} 5$-HT, excitability was reduced and produced a significant hyperpolarization of the membrane potential (from $-54.2 \pm 5$ to $-56.3 \pm 5 \mathrm{mV}$, repeated-measures oneway ANOVA, Bonferroni's post hoc test, $F_{(19,57)}=20.99$, $p=0.0001$; Fig. $7 A i$, black/gray), resulting in a hyperpolarization of $2.0 \pm 1 \mathrm{mV}$ from control $\left(n=20, t_{(19)}=5.3\right.$, $p<0.0001$, one-sample $t$ test; Fig. 7Aii). Similarly, at $0.1 \mu \mathrm{M}$ 5 -HT, there was a decrease in the firing frequency evoked by injection of $1.5 \times$ rheobase current (to $69.2 \pm 47 \%$ of control, one-sample $t$ test, $t_{(12)}=2.3, p=0.03$; Fig. $7 \mathrm{Bi}-\mathrm{Biii}$, black/ 


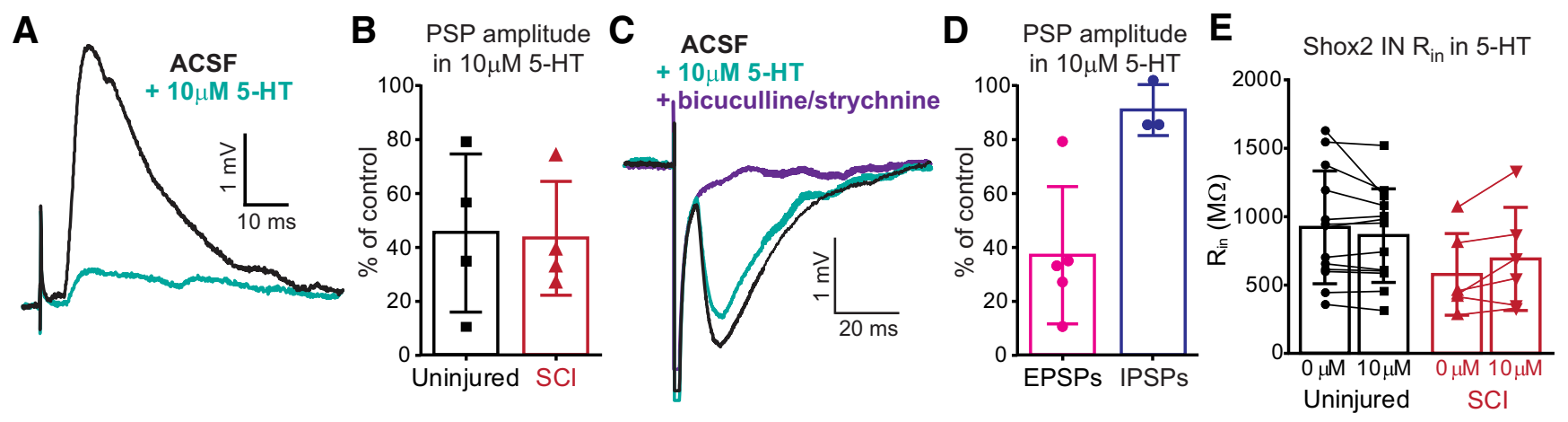

Figure 6. Serotonergic modulation of sensory afferent transmission to Shox2 INs. A, EPSPs evoked by stimulation of dorsal roots in control conditions (ACSF, artificial cerebrospinal fluid, black trace) and after the application of $10 \mu \mathrm{m}$ 5-HT (teal trace). B, PSP amplitude after 5-HT, normalized to control amplitude from uninjured (black bar) and SCI (red bar) mice. C, IPSPs evoked by stimulation of dorsal roots in control conditions (black trace), after the application of 5-HT (teal trace) and bicuculline and strychnine (purple trace). D, PSP amplitude after 5-HT, normalized to control amplitude from EPSPs (pink bar) and IPSPs (blue bar). E, Input resistance of Shox2 INs in control (left) and during 5-HT $10 \mu \mathrm{m}$ (right) from uninjured (black bars) and SCI (red bars) mice. Error bars indicate mean \pm SD. Dots represent individual cells.

Table 3. 5-HT effects on Shox2 in properties ${ }^{a}$

\begin{tabular}{|c|c|c|c|c|c|c|c|}
\hline & $\begin{array}{l}\text { Control } \\
\text { mean } \pm \text { SD }\end{array}$ & \multicolumn{2}{|l|}{$0.1 \mu \mathrm{m} \mathrm{5-HT}$} & \multicolumn{2}{|l|}{$1 \mu \mathrm{m} 5-\mathrm{HT}$} & \multicolumn{2}{|l|}{$10 \mu \mathrm{m} 5-\mathrm{HT}$} \\
\hline \multicolumn{8}{|l|}{ Uninjured } \\
\hline$E_{m}, \Delta$ from control & $\mathrm{N} / \mathrm{A}$ & $-2.0 \pm 1$ & $<0.0001^{*}$ & $1.0 \pm 2$ & 0.1 & $2.5 \pm 2$ & $0.02^{*}$ \\
\hline Input resistance (m $\Omega$ ) & $901 \pm 471$ & $862 \pm 430$ & $>0.9$ & $869 \pm 479$ & $>0.9$ & $848 \pm 430$ & $>0.9$ \\
\hline Capacitance (pF) & $41.6 \pm 14$ & $39.5 \pm 12$ & $>0.9$ & $44.2 \pm 19$ & $>0.9$ & $41.3 \pm 13$ & $>0.9$ \\
\hline Time constant (ms) & $39.3 \pm 24$ & $36.2 \pm 23$ & 0.8 & $38.9 \pm 22$ & $>0.9$ & $35.9 \pm 17$ & 0.6 \\
\hline Rheobase current (pA) & $24.8 \pm 15$ & $25.2 \pm 17$ & $>0.9$ & $23.7 \pm 16$ & $>0.9$ & $22.4 \pm 18$ & 0.1 \\
\hline Voltage threshold (mV) & $-37.4 \pm 3$ & $-38.8 \pm 3$ & $0.003^{*}$ & $-40.5 \pm 3$ & $<0.0001^{*}$ & $-41.7 \pm 4$ & $<0.0001^{*}$ \\
\hline Firing frequency at $1.5 \times$ rheobase ( $\%$ of control) & N/A & $69.2 \pm 47$ & $0.03^{*}$ & $99.9 \pm 44$ & 0.9 & $130.7 \pm 85$ & 0.2 \\
\hline Spontaneous firing frequency $(\mathrm{Hz})$ & $0.48 \pm 0.8$ & $0.08 \pm 0.1$ & $0.03^{*}$ & $0.40 \pm 0.4$ & $>0.9$ & $0.94 \pm 1.1$ & 0.01 \\
\hline \multicolumn{8}{|l|}{$\mathrm{SCl}$} \\
\hline Membrane potential (mV) & $-53.9 \pm 7$ & $-51.7 \pm 6$ & 0.2 & $-49.9 \pm 6$ & $0.01^{*}$ & $-48.6 \pm 6$ & $0.005^{*}$ \\
\hline$E_{m}, \Delta$ from control & $\mathrm{N} / \mathrm{A}$ & $2.2 \pm 3$ & 0.05 & $4.0 \pm 3$ & $0.003^{*}$ & $5.3 \pm 6$ & $0.003^{*}$ \\
\hline Input resistance (м $\Omega$ ) & $576 \pm 297$ & $700 \pm 411$ & 0.2 & $649 \pm 373$ & 0.5 & $688 \pm 377$ & 0.2 \\
\hline Capacitance (pF) & $43.9 \pm 11$ & $38.1 \pm 9$ & 0.07 & $39.6 \pm 12$ & 0.5 & $42.9 \pm 12$ & $>0.9$ \\
\hline Time constant (ms) & $26.4 \pm 16$ & $28.3 \pm 19$ & $>0.9$ & $28.1 \pm 15$ & $>0.9$ & $34.4 \pm 23$ & 0.5 \\
\hline Rheobase current (pA) & $24.5 \pm 11$ & $18.5 \pm 6$ & 0.4 & $18.5 \pm 7$ & 0.5 & $17.7 \pm 7$ & 0.08 \\
\hline Voltage threshold (mV) & $-33.0 \pm 3$ & $-36.8 \pm 3$ & 0.11 & $-37.8 \pm 3$ & $0.005^{*}$ & $-38.9 \pm 4$ & $0.001^{*}$ \\
\hline Firing frequency at $1.5 \times$ rheobase (\% of control) & $\mathrm{N} / \mathrm{A}$ & $167.8 \pm 88$ & $0.02^{*}$ & $173.7 \pm 98$ & $0.03^{*}$ & $185.3 \pm 85$ & $0.01^{*}$ \\
\hline Spontaneous firing frequency $(\mathrm{Hz})$ & $0.24 \pm 0.3$ & $0.66 \pm 0.7$ & 0.7 & $1.1 \pm 0.9$ & $0.02^{*}$ & $1.94 \pm 2.2$ & $0.001^{*}$ \\
\hline
\end{tabular}

${ }^{a} p$ values refer to Bonferroni's or Dunn's post hoc tests, as noted below. Comparisons for uninjured: membrane potential, repeated-measures one-way ANOVA $\left(F_{(19,57)}=20.99\right)$ with Bonferroni's post hoc test; Em $\Delta$ from control, one-sample unpaired $t$ test $\left(0.1 \mu \mathrm{m}, t_{(19)}=5.2 ; 1 \mu \mathrm{m}, t_{(19)}=1.6 ; 10 \mu \mathrm{m}, t_{(19)}=4.3\right)$; input resistance, Friedman $\chi_{(3)}^{2}=0.6$ with Dunn's post hoc test; capacitance, repeated-measures one-way ANOVA $\left(F_{(16,48)}=0.8\right)$ with Bonferroni's post hoc test; time constant, Friedman $\chi_{(3)}^{2}=2.9$ with Dunn's post hoc test; rheobase current, Friedman $\chi_{(3)}^{2}=5.4$ with Dunn's post hoc test; voltage threshold, repeated-measures one-way ANOVA $\left(F_{(16,48)}=72.1\right)$ with Bonferroni's post hoc test; firing frequency at $1.5 \times$ rheobase (\% of control), one-sample unpaired $t$ test $\left(0.1 \mu \mathrm{m}, t_{(12)}=2.3 ; 1 \mu \mathrm{m}, t_{(12)}=0.008 ; 10 \mu \mathrm{m}, t_{(12)}=1.3\right)$; spontaneous firing frequency, Friedman $\chi_{(3)}^{2}=21.7$ with Dunn's post hoc test. Comparisons for SCl: membrane potential, Friedman $\chi_{(3)}^{2}=12.2$ with Dunn's post hoc test; Em $\Delta$ from control, Wilcoxon signed ranked test $(0.1 \mu \mathrm{m}, \mathrm{W}=33$; $1 \mu \mathrm{m}$, $\mathrm{W}=45 ; 10 \mu \mathrm{m}, \mathrm{W}=52)$; input resistance, Friedman $\chi_{(3)}^{2}=3.4$ with Dunn's post hoc test; capacitance, Friedman $\chi_{(3)}^{2}=5.2$ with Dunn's post hoc test; time constant, Friedman $\chi_{(3)}^{2}=1.9$ with Dunn's post hoc test; rheobase current, Friedman $\chi^{2}{ }_{(3)}=7.3$ with Dunn's post hoc test; voltage threshold, Friedman $\chi^{2}{ }_{(3)}=15.2$ with Dunn's post hoc test; firing frequency at $1.5 \times$ rheobase (\% of control), Wilcoxon signed ranked test $(0.1 \mu \mathrm{m}$, $\mathrm{W}=32 ; 1 \mu \mathrm{m}, \mathrm{W}=30 ; 10 \mu \mathrm{m}, \mathrm{W}=39)$; spontaneous firing frequency, Friedman $\chi_{(3)}^{2}=14.3$ with Dunn's post hoc test.

*Statistical significance: $p<0.05$.

gray) and a reduction in spontaneous firing frequency at resting membrane potential (from $0.48 \pm 0.8$ to $0.08 \pm 0.1 \mathrm{~Hz}$, Friedman $\chi_{(3)}^{2}=21.7$, Dunn's post hoc test, $p=0.03$; Fig. 7Ci, $\mathrm{Cii}$, black/gray). Measurements taken at $1 \mu \mathrm{M}$ 5-HT were typically not significantly different from control conditions (Table 2; Fig. 7); however, $10 \mu \mathrm{M} \mathrm{5-HT} \mathrm{significantly} \mathrm{increased} \mathrm{the}$ excitability of Shox2 INs and produced a depolarization of the membrane potential (from $-54.2 \pm 5$ in control to $-51.7 \pm$ $3 \mathrm{mV}$, repeated-measures one-way ANOVA, Bonferroni post hoc test, $F_{(19,57)}=20.99, p=0.001$; Fig. $7 \mathrm{~A} i$, black/gray), which was $2.5 \pm 2 \mathrm{mV}$ more depolarized than control values $(n=20$, one-sample $t$ test, $\left.t_{(19)}=4.3, p=0.02\right)$. An increase in the firing frequency was evoked by injection of $1.5 \times$ rheobase current in 9 of 13 neurons (Fig. 7Bi-Biii, black/gray), the mean of which $\left(130.7 \pm 85 \%\right.$ of control) was not significant (one-sample $t$ test, $t_{(11)}$ $=1.3, p=0.2)$, and an increase in spontaneous firing frequency was observed (from $0.48 \pm 0.8$ in control to $0.94 \pm 1 \mathrm{~Hz}$, Friedman $\chi_{(3)}^{2}$ $=21.7$, Dunn's post hoc test, $p=0.01$; Fig. 7Ci,Cii, black/gray). Additionally, in a subset of Shox2 INs, we also recorded the responses for 0.01 and $100 \mu \mathrm{m} 5-\mathrm{HT}$. The values at these concentrations are not significantly different from control, possibly because of the low number of Shox 2 INs withstanding the full protocol $(n=5)$; however, a dual response is evident from the curves (Fig. 7Aii,Biii, black).

We found that 5-HT modulation of Shox 2 INs is significantly different in chronic SCI mice. In SCI mice, the decrease in 
$\mathbf{A}_{\mathbf{i}}$

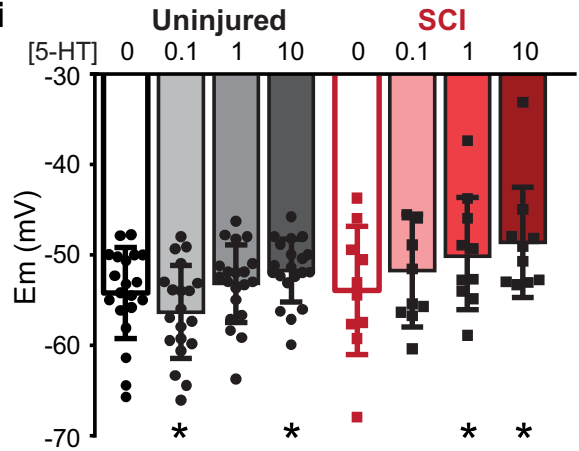

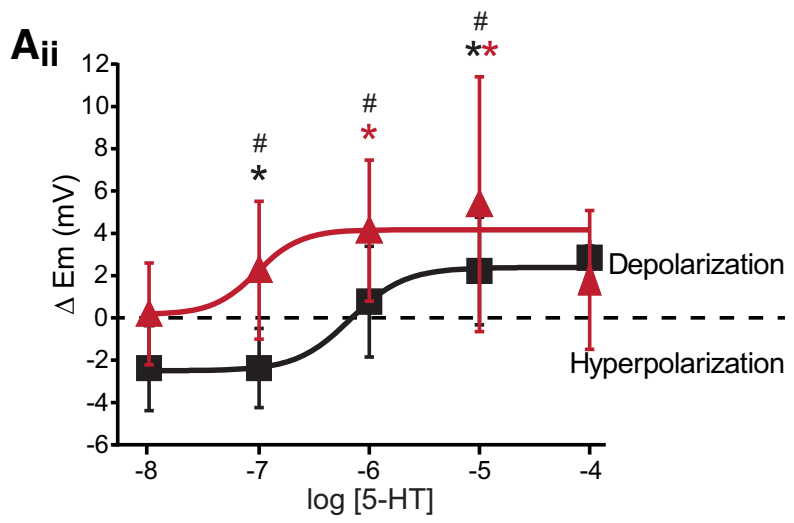

$B_{\text {iii }}$

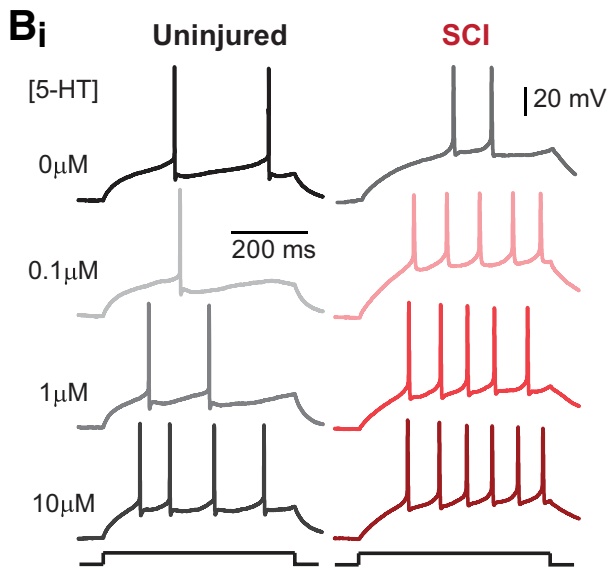

$B_{i i}$
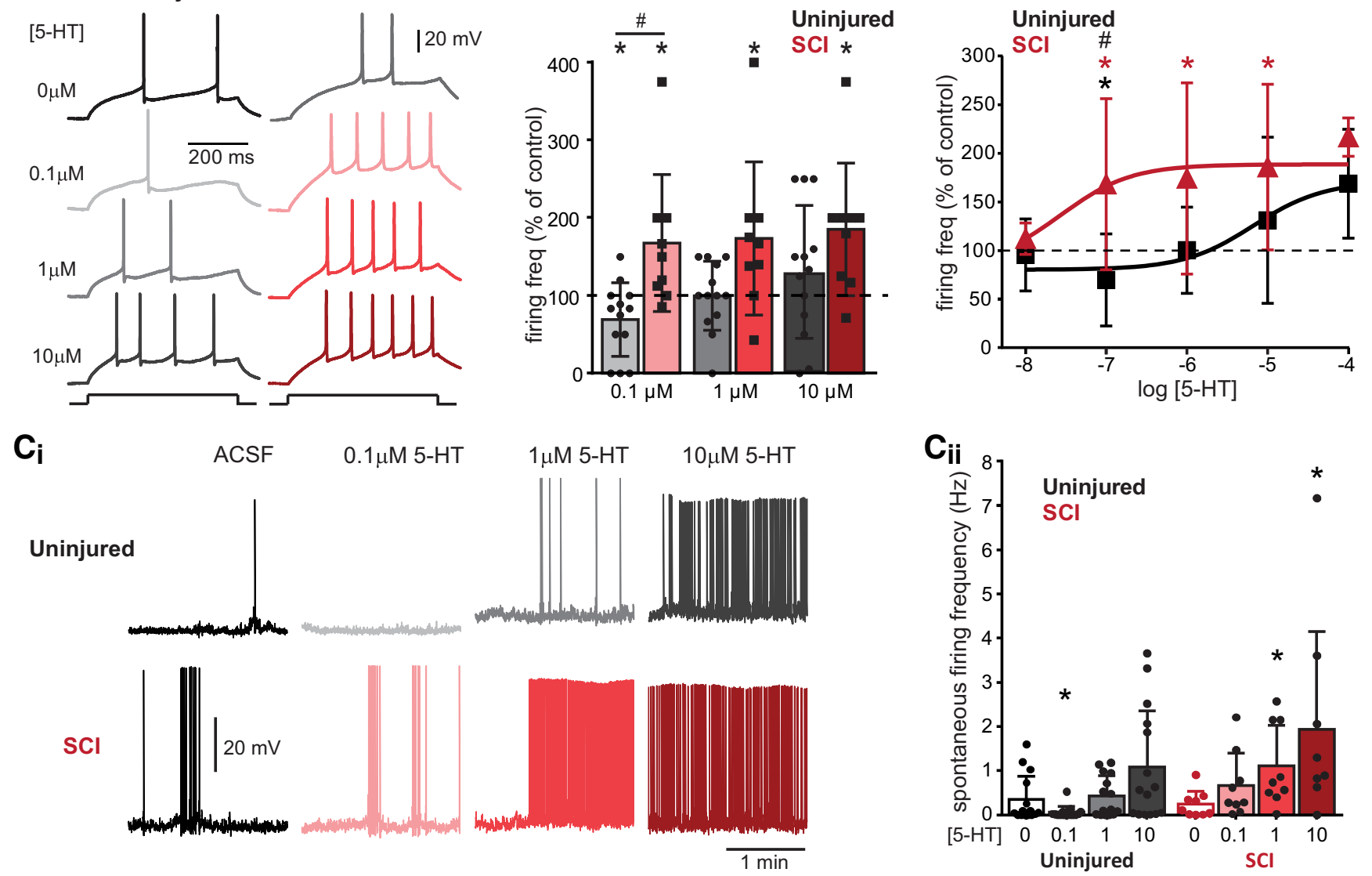

Figure 7. Serotonergic modulation of Shox2 INs changes after SCI. Ai, Changes in the membrane potential of Shox2 INs from uninjured (black/gray bars) and SCI (red bars) mice after application of increasing concentrations of 5-HT. One-way ANOVA with Bonferroni's post hoc test to compare control and 5-HT concentrations within each group: ${ }^{*} p<0.05$. Aii, Drug concentrationresponse curves for the changes in the membrane potential in Shox2 INs from uninjured (black) and SCI (red) mice. Wilcoxon signed rank test to compare each value with control: ${ }^{*} p<0.05$. Two-way ANOVA with Bonferroni's post hoc test to compare between uninjured and SCl in control and after each 5-HT concentration: ${ }^{*} p<0.05$. Bi, Shox2 IN response to injection of $1.5 \times$ rheobase current. Examples of Shox2 IN recordings from uninjured (left) and SCI (right) mice in control conditions and after the application of 0.1, 1, and 10 $\mu \mathrm{M} 5$-HT. Bii, Summary of action potential firing frequency in Shox2 INs in response to $1.5 \times$ rheobase current as a percentage of the control after the application different concentrations of 5-HT, from uninjured (black bars) and $\mathrm{SCl}$ (red bars) mice. Wilcoxon signed rank test to compare each value with control: ${ }^{*} p<0.05$. Two-way ANOVA with Bonferroni's post hoc test to compare between uninjured and SCI in control and after each 5-HT concentration: ${ }^{*} p<0.05$. Biii, Drug concentration-response curves for the changes in the action potential firing frequency of Shox2 INs from uninjured (black) and $\mathrm{SCI}$ (red) mice. Wilcoxon signed rank test to compare each value with control: ${ }^{*} p<0.05$. Two-way ANOVA with Bonferroni's post hoc test to compare between uninjured and $\mathrm{SCl}$ in control and after each 5-HT concentration: ${ }^{*} p<0.05$. Ci, Spontaneous firing of Shox2 INs from uninjured (top traces) and SCI (bottom traces) mice in control conditions and after application of increasing concentrations of 5-HT. Cii, Mean spontaneous firing frequency at resting membrane potential of Shox2 INs in control conditions from uninjured (black) and SCl (red) and after the application of different concentrations of 5-HT. Friedman test with Dunn's post hoc test to compare each value with control: * $p<0.05$. Two-way ANOVA with Bonferroni's post hoc test to compare between uninjured and SCl in control and after each 5-HT concentration: ${ }^{\#} p<0.05$. Error bars indicate mean \pm SD. Dots represent individual cells.

excitability of Shox2 INs at low 5-HT concentrations is lost, whereas an increase in excitability is evident. As such, $0.1 \mu \mathrm{M} 5-$ HT did not hyperpolarize Shox2 IN after SCI (Fig. 7Ai,Aii). Indeed, $0.1 \mu \mathrm{M}$ 5-HT depolarized 7 of 10 Shox2 INs, although the mean depolarization was not significant (from $-53.9 \pm 7$ control to $-51.7 \pm 6 \mathrm{mV}$, Friedman $\chi_{(3)}^{2}=12.2$, Dunn's post hoc test, $p=0.2$; Fig. 7Ai, red). Significant depolarizations of Shox2 IN membrane potentials resulted from application of both 1 and $10 \mu \mathrm{M} 5-\mathrm{HT}$ (from $-53.9 \pm 7 \mathrm{mV}$ control to $-49.9 \pm 6 \mathrm{mV}$, and $-48.6 \pm 6 \mathrm{mV}$ after 1 and $10 \mu \mathrm{M}$, respectively, Friedman $\chi_{(3)}^{2}=$ 
Table 4. Comparison of 5-HT effects on Shox2 from uninjured versus SCI with mixed two-way ANOVA and Bonferroni's post hoc test ${ }^{a}$

\begin{tabular}{|c|c|c|c|c|c|c|c|c|c|}
\hline & \multicolumn{3}{|l|}{$0.1 \mu \mathrm{M} \mathrm{5-HT}$} & \multicolumn{3}{|l|}{$1 \mu \mathrm{m} \mathrm{5-HT}$} & \multicolumn{3}{|l|}{$10 \mu \mathrm{m} 5-\mathrm{HT}$} \\
\hline & Uninjured & $\mathrm{SCl}$ & Post hoc test $p$ & Uninjured & $\mathrm{SCl}$ & Post hoc test $p$ & Uninjured & $\mathrm{SCl}$ & Post hoc test $p$ \\
\hline $\mathrm{E}_{\mathrm{m}}, \Delta$ from control & $-2.0 \pm 1$ & $2.2 \pm 3$ & $0.001^{*}$ & $1.0 \pm 2$ & $4.0 \pm 3$ & $0.02^{*}$ & $2.5 \pm 2$ & $5.3 \pm 6$ & 0.05 \\
\hline Firing frequency at $1.5 \times$ rheobase ( $\%$ of control) & $69.2 \pm 47$ & $167.8 \pm 88$ & $0.01^{*}$ & $99.9 \pm 44$ & $173.7 \pm 98$ & 0.07 & $130.7 \pm 85$ & $185.3 \pm 85$ & 0.2 \\
\hline
\end{tabular}

${ }^{a} \mathrm{E}_{\mathrm{m}}, \Delta$ from control: interaction, $F_{(2,56)}=0.7, p=0.4$; groups $F_{(1,28)}=13.6, p=0.001$; concentration $\left.F_{(3,56)}=13.8, p<0.0001\right)$; firing frequency at $1.5 \times$ rheobase, $\%$ of control: interaction, $F_{(2,40)}=2.4, p=0.09 ;$ groups $F_{(1,20)}=6.1, p=0.02$; concentration $F_{(3,66)}=8.0, p=0.001$.

*Statistical significance: $p<0.05$

21.7, Dunn's post hoc test, $p=0.01$ and $p=0.005$; Fig. $7 A i$, red). When considering the depolarization of individual neurons $(\triangle \mathrm{Em})$, 1 and $10 \mu \mathrm{M} 5$-HT depolarized the neurons by $4.0 \pm 3$ and $5.3 \pm$ $6 \mathrm{mV}$, respectively $(n=10$, Wilcoxon signed rank test, $\mathrm{W}=45$, $p=0.003$ and $\mathrm{W}=52, p=0.003$, respectively; Fig. 7Aii, red). There was a significant increase in the firing frequency evoked by the application of $1.5 \times$ rheobase current at $0.1,1$, and $10 \mu \mathrm{M} \mathrm{5-HT}$ (to $167 \pm 88 \%, 173 \pm 98 \%$, and $185 \pm 85 \%$ of control after $0.1,1$, and $10 \mu \mathrm{M}$, respectively, Wilcoxon signed rank test, $\mathrm{W}=32, p=0.02$ : $\mathrm{W}=30, p=0.03$ and $\mathrm{W}=39, p=0.01$; Fig. $7 B i-B i i i, \quad$ red). Furthermore, there was a significant increase in the spontaneous firing frequency of Shox 2 INs from SCI mice at 1 and $10 \mu \mathrm{M} 5-\mathrm{HT}$ (from $0.24 \pm 0.2$ in control to $1.1 \pm 0.9$, and $1.9 \pm 2.2 \mathrm{~Hz}$ for 1 and $10 \mu \mathrm{M}$, respectively, Friedman $\chi_{(3)}^{2}=14.3$, Dunn's post hoc test, $p=0.02$ and $p=0.001$; Fig. $7 \mathrm{Ci}, \mathrm{Cii}$, red). The increase in spontaneous firing frequency was concomitant with both a depolarization of the membrane potential and a hyperpolarization of voltage thresholds for action potential generation in Shox2 INs from both uninjured and SCI mice (Table 3).

The curves generated by the administration of 5-HT from 0.01 to $100 \mu \mathrm{M}$ (Fig. 7Bii,Ciii) showed a shift in Shox2 IN from SCI mice, suggesting 5-HT supersensitivity (leftward shift) and enhancement of excitatory effects (upward shift). Furthermore, there are significant differences when we compare the effects of the same concentrations of drugs on Shox2 INs from uninjured and SCI mice (Table 4; Fig. 7). The depolarization of individual Shox2 INs $(\Delta \mathrm{Em})$ was significantly higher at $0.1,1$, and $10 \mu \mathrm{M} \mathrm{5-}$ HT in SCI mice compared with uninjured mice (mixed two-way ANOVA [interaction $F_{(2,26)}=0.7, p=0.4$; groups $F_{(1,28)}=13.6$, $p=0.001$; concentration $\left.F_{(3,56)}=13.8, p<0.0001\right]$ with Bonferroni's post hoc test, $-2.0 \pm 1$ and $2.2 \pm 3$ for $0.1 \mu \mathrm{M} 5-\mathrm{HT}$ from uninjured and SCI mice, respectively, $p=0.001 ; 1.0 \pm 2$ and $4.0 \pm 3$ for $1 \mu \mathrm{M} \mathrm{5-HT} \mathrm{from} \mathrm{uninjured} \mathrm{and} \mathrm{SCI} \mathrm{mice,} \mathrm{respectively,}$ $p=0.02$; and $2.5 \pm 2$ and $5.3 \pm 6$ for $10 \mu \mathrm{M} 5$-HT from uninjured and SCI mice, respectively, $p=0.05$; Fig. 7 Aii). Additionally, at 0.1 $\mu \mathrm{M} 5-\mathrm{HT}$, the firing frequency evoked by injection of $1.5 \times$ rheobase current was higher in Shox 2 INs from SCI mice compared with uninjured animals $(69.2 \pm 88$ and $167.8 \pm 88 \%$ of control from uninjured and SCI mice, respectively, mixed two-way ANOVA, interaction $F_{(2,40)}=2.9, p=0.09$; groups $F_{(1,20)}=6.19$, $p=0.02$; concentration $F_{(3,66)}=8.08, p=0.001$, Bonferroni post hoc test, $p=0.01$; Fig. $7 \mathrm{Bi}-\mathrm{Biii}$ ). At $10 \mu \mathrm{M} 5-\mathrm{HT}$, the spontaneous firing frequency was higher in Shox2 INs from SCI mice than uninjured mice $(0.94 \pm 1$ and $1.94 \pm 2$ from uninjured and SCI mice, respectively, mixed two-way ANOVA interaction $F_{(3,84)}=2.39, p=0.07$; groups $F_{(1,28)}=4.28, p=0.04$; concentration $F_{(3,84)}=8.8$, $p<0.0001$ with Bonferroni post hoc test, $p=0.04$; Fig. 7Ci,Cii). Together, 5-HT modulates Shox2 INs by at least two different mechanisms in uninjured mice. The differential modulation of Shox 2 INs by 5 -HT in uninjured cord suggests that the activation of at least two different receptor subtypes is involved. After SCI, excitatory modulation is increased and/or there is a decrease in inhibitory modulation.

\section{Serotonin receptors involved in Shox 2 modulation}

The identity of the 5-HT receptors involved in the serotonergic modulation of the CPG and locomotor control has been suggested largely by observations of motor output, with $5-\mathrm{HT}_{2}$ and $5-\mathrm{HT}_{7}$ receptors producing pro-locomotor effects (Hochman, 2001; Madriaga et al., 2004; Liu and Jordan, 2005; Pearlstein et al., 2005; Dunbar et al., 2010; Slawinska et al., 2014; Oueghlani et al., 2020). However, recordings of motor output limits the ability to determine differential participation of $5-\mathrm{HT}$ receptors at the pattern formation, rhythm generation, and motor neuron levels (Liu et al., 2009; Cabaj et al., 2017; Majczyński et al., 2020). Serotonin receptor agonists are used to improve locomotor outcomes in animal models of SCI (Kim et al., 2001; Landry and Guertin, 2004; Gerasimenko et al., 2007; Ichiyama et al., 2008; Courtine et al., 2009; van den Brand et al., 2012; Slawinska et al., 2014; Duru et al., 2015) and changes in the expression of 5- $\mathrm{HT}_{2 \mathrm{~A}}$ and $5-\mathrm{HT}_{2 \mathrm{C}}$ receptors after SCI has been reported (Fuller et al., 2005; Lee et al., 2007; Kong et al., 2010; Murray et al., 2010; Husch et al., 2012; Navarrett et al., 2012; Ren et al., 2013). 5-HT $5-\mathrm{HT}_{2 \mathrm{~A}}$, and $5-\mathrm{HT}_{7}$ receptor subtypes are expressed on locomotor-related neurons in lamina VI and VII in cat (Noga et al., 2009), but those involved in the serotonergic modulation of genetically identified CPG neurons in uninjured and after SCI are just starting to be elucidated (Husch et al., 2012).

In order to determine which 5-HT receptors are involved in the excitatory modulation of Shox 2 neurons, we first targeted the $5-\mathrm{HT}_{7}$ receptors on Shox $2 \mathrm{INs}$ by applying the $5-\mathrm{HT}_{1 \mathrm{~A} / 7}$ receptor agonist, 8-OH-DPAT, together with the $5-\mathrm{HT}_{1 \mathrm{~A}}$ receptor antagonist, WAY-100635 (Madriaga et al., 2004; Shay et al., 2005; Cotel et al., 2013). In Shox2 neurons from uninjured mice, the activation of $5-\mathrm{HT}_{7}$ receptors depolarized the membrane potential (from $-54.4 \pm 6$ in WAY-100635 to $-50.8 \pm 7 \mathrm{mV}$ in WAY$100635+8-\mathrm{OH}-\mathrm{DPAT}$, paired $t$ test, $t_{(7)}=3.2, p=0.01, n=8$; Fig. $8 A$; Table 5). Similarly, in Shox 2 neurons from SCI mice, the activation of $5-\mathrm{HT}_{7}$ receptors, depolarized the membrane potential (from $-52.4 \pm 5$ in WAY-100635 to $-48.8 \pm 7 \mathrm{mV}$ in WAY100635 and 8-OH-DPAT, paired $t$ test, $t_{(11)}=2.9, p=0.01$, $n=12$; Fig. $8 A$; Table 5). The depolarization of Shox 2 INs by the activation of $5-\mathrm{HT}_{7}$ receptors was not significantly different between uninjured and SCI mice (see Table 8). However, the rheobase current was also reduced in Shox2 neurons from SCI mice (from $23.5 \pm 11$ in WAY-100635 to $-18.7 \pm 11 \mathrm{pA}$ in WAY-100635 + 8-OH-DPAT, Wilcoxon test, $\mathrm{W}=-47, p=0.01$, $n=12$; Fig. $8 B$; Table 5), which represents a $22.2 \pm 20 \%$ reduction with respect to the antagonist only $\left(n=12, t_{(12)}=3.96\right.$, $p=0.001$, one-sample $t$ test; see Table 8 ). Additionally, the voltage threshold for action potential was reduced in Shox2 neurons from SCI mice after the activation of $5-\mathrm{HT}_{7}$ receptors (from $-35.0 \pm 3$ in WAY-100635 to $-36.2 \pm 3 \mathrm{mV}$ in WAY$100635+8-\mathrm{OH}-\mathrm{DPAT}$, paired $t$ test, $t_{(11)}=2.6, p=0.02, n=12$; Table 5). Sustained depolarizations indicative of plateau potentials (Hounsgaard and Kiehn, 1989) became evident in 25\% (5 of 20) Shox 2 INs after the activation of $5-\mathrm{HT}_{7}$ receptors (Fig. $8 \mathrm{C}$ ). 

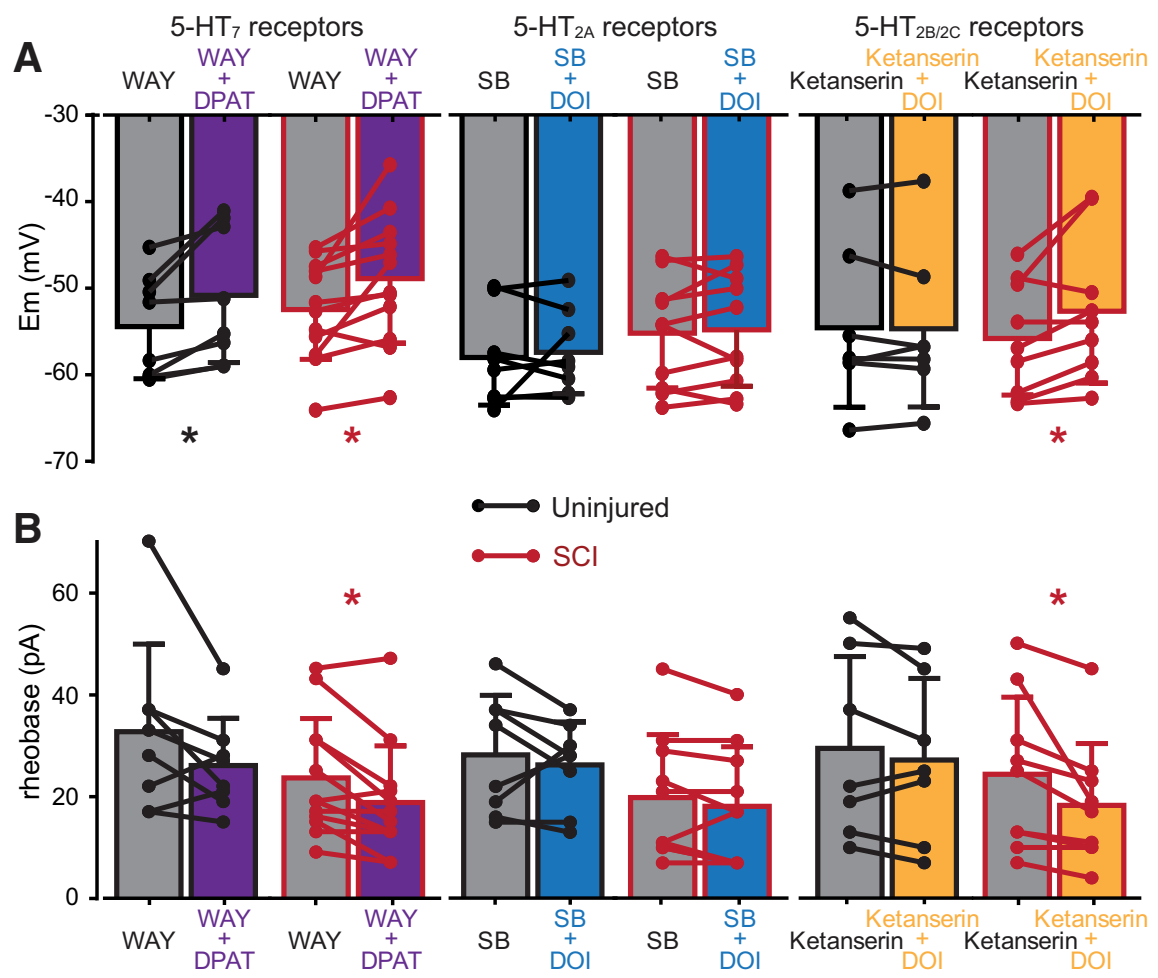

C WAY
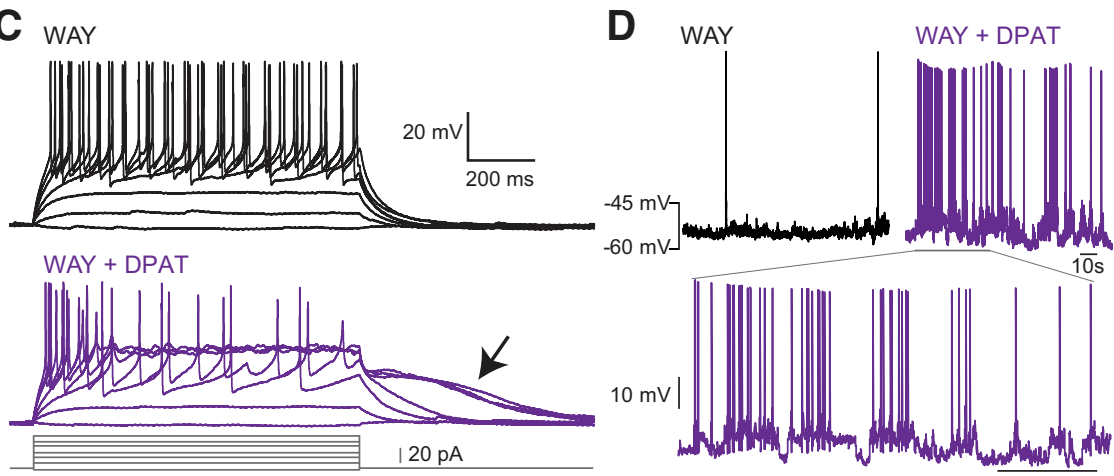

Figure 8. Serotonergic receptors involved in the modulation of Shox2 INs. $A$, Changes in the membrane potential of Shox2 INs from uninjured (black) and SCI (red bars) mice are compared between application of specific 5-HT receptor antagonist (gray) and antagonist + agonist to isolate the activation of $5-\mathrm{HT}_{7}$ (purple), $5-\mathrm{HT}_{2 \mathrm{~A}}$ (blue), and $5-\mathrm{HT}_{2 \mathrm{~B} / 2 \mathrm{C}}$ (orange) receptors. Paired $t$ test was used to compare antagonist and antagonist + agonist: ${ }^{*} p<0.05$. $\boldsymbol{B}$, Changes in the rheobase current of Shox2 INs from uninjured (black bars) and SCI (red bars) mice compared between after application of specific 5-HT receptor antagonist and antagonist + agonist to isolate the activation of specific receptor subtypes (as in $A$ ). Paired $t$ test or Wilcoxon test to compare antagonist and antagonist + agonist effects: ${ }^{*} p<0.05$. C, Example of a Shox2 IN response to injection depolarizing current steps from an SCI mouse after the application of WAY 100635 (top traces) and after the application of WAY-100635 + 8-0H-DPAT (bottom traces). Arrow indicates the presence of a sustained depolarization. $\boldsymbol{D}$, Spontaneous firing of a Shox2 IN in WAY-100635 and after the addition of 8-OH-DPAT. Bottom inset, Oscillations of the membrane potentials. WAY, WAY-100635; DPAT, 8-OH-PDAT; SB, SB206553.

Spontaneous oscillations emerged in 3 of the 5 neurons with sustained depolarizations after 8-OH-DPAT (Fig. 8D). These results demonstrate that the activation of $5-\mathrm{HT}_{7}$ receptors increases the excitability of Shox2 INs both in uninjured and in SCI mice.

We next targeted the $5-\mathrm{HT}_{2}$ receptors using the agonist, DOI, together with the specific antagonists for either $5-\mathrm{HT}_{2 \mathrm{~A}}$ receptors, ketanserin (Hochman, 2001; Liu and Jordan, 2005; Oueghlani et al., 2020), or 5- $\mathrm{HT}_{2 \mathrm{~B} / 2 \mathrm{C}}$ receptors, SB206553 (Kao et al., 2006; Fouad et al., 2010), to determine actions at 5- $\mathrm{HT}_{2 \mathrm{~B} / 2 \mathrm{C}}$ and $5-\mathrm{HT}_{2 \mathrm{~A}}$ receptors, respectively. The effects produced by the agonist and antagonist combined were compared with the effects produced by antagonist alone. We found that, in both uninjured and SCI mice, the activation of $5-\mathrm{HT}_{2 \mathrm{~A}}$ receptors had no significant effect on any of the intrinsic properties of Shox2 INs (Table 6; Table 8).
Similarly, the activation of $5-\mathrm{HT}_{2 \mathrm{~B} / 2 \mathrm{C}}$ receptors did not significantly change any of the intrinsic properties of Shox2 neurons measured from uninjured mice (Table 7). Interestingly, the activation of $5-\mathrm{HT}_{2 \mathrm{~B} / 2 \mathrm{C}}$ receptors reduced the rheobase in Shox 2 neurons from SCI mice (from $24.3 \pm 15$ in ketanserin to $18.2 \pm$ $12 \mathrm{pA}$ in ketanserin and DOI, paired $t$ test, $t_{(8)}=2.58, p=0.03, n=9$; Fig. $8 B$; Table 7), which represents a reduction of $26.3 \pm 17 \%$ with respect to the solution with the antagonist only $\left(n=9, t_{(8)}=4.1\right.$, $p=0.003$, one-sample $t$ test; Table 8). Further, 5- $\mathrm{HT}_{2 \mathrm{~B} / 2 \mathrm{C}}$ receptor activation depolarized the membrane potential (from $-55.7 \pm 6$ in ketanserin to $-52.6 \pm$ $8 \mathrm{mV}$ in ketanserin and DOI, paired $t$ test, $t_{(8)}=2.69, p=0.02, n=9$; Fig. $8 A$; Table 7). The depolarization of the membrane potential was significant in Shox2 neurons from SCI compared with the effects observed from uninjured mice (SCI: $3.1 \pm 3 \mathrm{mV}, \quad n=9$, uninjured: $-0.1 \pm 1 \mathrm{mV}, n=7$, unpaired $t$ test, $t_{(14)}=2.29, p=0.03$; Table 8).

Together, these data suggest that the observed excitatory effects of 5-HT on Shox 2 neurons from uninjured mice are mediated by $5-\mathrm{HT}_{7}$ receptors. Further, after SCI, activation of both $5-\mathrm{HT}_{2 \mathrm{~B} / 2 \mathrm{C}}$ and $5-\mathrm{HT}_{7}$ receptors results in excitatory responses in Shox2 neurons, suggesting that observed 5-HT supersensitivity is due to the expression and activation of $5-\mathrm{HT}_{2 \mathrm{~B} / 2 \mathrm{C}}$ receptors, in addition to $5-\mathrm{HT}_{7}$ receptors.

\section{Discussion}

In the present study, we demonstrate that intrinsic excitability and firing properties of adult Shox2 INs are not altered after SCI. Alterations are observed, however, in sensory afferent transmission to and 5-HT modulation of Shox2 INs, facilitating an overall excitatory response of Shox2 INs to both afferent and neuromodulatory control. Further, serotonergic modulation of Shox 2 INs is mediated by $5-\mathrm{HT}_{7}$ receptors, but not $5-\mathrm{HT}_{2}$ receptors, in uninjured and by both $5-\mathrm{HT}_{7}$ and $5-\mathrm{HT}_{2 \mathrm{~B} / 2 \mathrm{C}}$ receptors in SCI mice.

\section{Adult Shox2 INs}

Most previous studies examining the cellular properties, circuitry, and function of genetically identified INs were performed in neonatal and juvenile preparations (Goulding, 2009; Kiehn, 2016). Although genetic manipulations have allowed for functional identification in adults (Zhang et al., 2008; Talpalar et al., 2013; Britz et al., 2015; Falgairolle and O'Donovan, 2019), information on the cellular properties of adult neurons is currently scant. One exception is the V2a INs (Husch et al., 2012, 2015), 
Table 5. Effects of $5-\mathrm{HT}_{7}$ receptor activation on Shox2 in properties

\begin{tabular}{|c|c|c|c|c|c|c|c|c|}
\hline & \multicolumn{8}{|c|}{$5-\mathrm{HT}_{7}$ receptor activation ${ }^{a}$} \\
\hline & \multicolumn{4}{|l|}{ Uninjured } & \multicolumn{4}{|l|}{$\mathrm{SCl}$} \\
\hline & $\begin{array}{l}\text { WAY-100635 } \\
\text { mean } \pm S D\end{array}$ & $\begin{array}{l}\text { WAY-100635 } \\
+8-0 \mathrm{H}-\mathrm{DPAT} \\
\text { mean } \pm \text { SD }\end{array}$ & $\begin{array}{l}\text { Paired } t \text { test or } \\
\text { Wilcoxon (W) }\end{array}$ & $p$ & $\begin{array}{l}\text { WAY-100635 } \\
\text { mean } \pm S D\end{array}$ & $\begin{array}{l}\text { WAY-100635 } \\
+8-0 \mathrm{H}-\mathrm{DPAT} \\
\text { mean } \pm \text { SD }\end{array}$ & $\begin{array}{l}\text { Paired } t \text { test or } \\
\text { Wilcoxon (W) }\end{array}$ & $p$ \\
\hline Membrane potential (mV) & $-54.4 \pm 6$ & $-50.8 \pm 7$ & $t_{(7)}=3.2$ & $0.01^{*}$ & $-52.4 \pm 5$ & $-48.8 \pm 7$ & $t_{(11)}=2.9$ & $0.01^{*}$ \\
\hline Input resistance $(\mathrm{M} \Omega$ ) & $463.8 \pm 128$ & $490.9 \pm 156$ & $t_{(7)}=1.3$ & 0.2 & $660.1 \pm 318$ & $717.0 \pm 453$ & $W=34$ & 0.2 \\
\hline Rheobase current (pA) & $32.6 \pm 17$ & $26.0 \pm 9$ & $t_{(7)}=1.8$ & 0.1 & $23.5 \pm 11$ & $18.7 \pm 11$ & $W=-47$ & $0.01^{*}$ \\
\hline Voltage threshold (mV) & $-36.7 \pm 3$ & $-36.6 \pm 3$ & $t_{(7)}=0.2$ & 0.8 & $-35.0 \pm 3$ & $-36.2 \pm 3$ & $t_{(11)}=2.6$ & $0.02^{*}$ \\
\hline $\begin{array}{l}\text { Spontaneous firing } \\
\text { frequency }(\mathrm{Hz})\end{array}$ & $0.12 \pm 0.17$ & $0.42 \pm 0.5$ & $W=8$ & 0.2 & $0.02 \pm 0.06$ & $0.13 \pm 0.33$ & $W=23$ & 0.1 \\
\hline
\end{tabular}

${ }^{a}$ For comparison of Shox2 IN properties from uninjured and SCI mice in ACSF and the antagonist of 5-HT $1 \mathrm{~A} / 7$ receptors (WAY-100635), see Extended Data Table 5-1.

*Statistical significance: $p<0.05$.

Table 6. Effects of 5- $\mathrm{HT}_{2 \mathrm{~A}}$ receptor activation on Shox2 in properties

\begin{tabular}{|c|c|c|c|c|c|c|c|c|}
\hline & \multicolumn{8}{|c|}{$5-\mathrm{HT}_{2 \mathrm{~A}}$ receptor activation ${ }^{a}$} \\
\hline & \multicolumn{4}{|l|}{ Uninjured } & \multicolumn{4}{|l|}{$\mathrm{SCl}$} \\
\hline & $\begin{array}{l}\text { SB206553 } \\
\text { mean } \pm \text { SD }\end{array}$ & $\begin{array}{l}\text { SB206553 + D0I } \\
\text { mean } \pm \text { SD }\end{array}$ & $\begin{array}{l}\text { Paired } t \text { test } \\
\text { or Wilcoxon }(\mathrm{W})\end{array}$ & $p$ & $\begin{array}{l}\text { SB206553 } \\
\text { mean } \pm \text { SD }\end{array}$ & $\begin{array}{l}\text { SB206553 + D0I } \\
\text { mean } \pm \text { SD }\end{array}$ & $\begin{array}{l}\text { Paired } t \text { test } \\
\text { or Wilcoxon }(\mathrm{W})\end{array}$ & $p$ \\
\hline Membrane potential (mV) & $-58.7 \pm 5$ & $-57.4 \pm 4$ & $t_{(7)}=0.4$ & 0.6 & $-55.2 \pm 6$ & $-54.7 \pm 6$ & $t_{(9)}=0.5$ & 0.6 \\
\hline Input resistance (M $\Omega$ ) & $710.2 \pm 250$ & $717.5 \pm 308$ & $t_{(7)}=0.1$ & 0.9 & $799.1 \pm 292$ & $912.2 \pm 374$ & $t_{(7)}=2.3$ & 0.05 \\
\hline Rheobase current (pA) & $28.2 \pm 11$ & $26.2 \pm 8$ & $t_{(7)}=0.7$ & 0.4 & $24.5 \pm 11$ & $18.5 \pm 6$ & $t_{(9)}=1.5$ & 0.1 \\
\hline Voltage threshold (mV) & $-36.9 \pm 4$ & $-37.9 \pm 4$ & $t_{(7)}=1.8$ & 0.1 & $-35.7 \pm 3$ & $-35.6 \pm 3$ & $t_{(9)}=0.1$ & 0.9 \\
\hline Spontaneous firing frequency $(\mathrm{Hz})$ & $0.04 \pm 0.07$ & $0.17 \pm 0.25$ & $W=25$ & $0.04^{*}$ & $0.11 \pm 0.24$ & $0.35 \pm 0.74$ & $W=5$ & 0.6 \\
\hline
\end{tabular}

${ }^{a}$ For comparison of Shox2 in properties from uninjured and SCI mice in ACSF and the 5- $\mathrm{HT}_{2 \mathrm{~B} / 2 \mathrm{C}}$ receptor antagonist (SB206553), see Extended Data Table 6-1.

*Statistical significance: $p<0.05$.

Table 7. Effects of $5-\mathrm{HT}_{2 \mathrm{~B} / 2 \mathrm{C}}$ receptor activation on Shox2 in properties

\begin{tabular}{|c|c|c|c|c|c|c|c|c|}
\hline & \multicolumn{8}{|c|}{ 5- $\mathrm{HT}_{2 \mathrm{~B} / 2 \mathrm{C}}$ receptor activation ${ }^{a}$} \\
\hline & \multicolumn{4}{|l|}{ Uninjured } & \multicolumn{4}{|l|}{$\mathrm{SCl}$} \\
\hline & $\begin{array}{l}\text { Ketanserin } \\
\text { mean } \pm S D\end{array}$ & $\begin{array}{l}\text { Ketanserin }+ \text { DOI } \\
\text { mean } \pm S D\end{array}$ & $\begin{array}{l}\text { Paired } t \text { test or } \\
\text { Wilcoxon }(\mathrm{W})\end{array}$ & $p$ & $\begin{array}{l}\text { Ketanserin } \\
\text { mean } \pm S D\end{array}$ & $\begin{array}{l}\text { Ketanserin }+ \text { DOI } \\
\text { mean } \pm S D\end{array}$ & $\begin{array}{l}\text { Paired } t \text { test or } \\
\text { Wilcoxon }(\mathrm{W})\end{array}$ & $p$ \\
\hline Membrane potential (mV) & $-54.6 \pm 9$ & $-54.7 \pm 9$ & $t_{(6)}=0.2$ & 0.8 & $-55.7 \pm 6$ & $-52.6 \pm 8$ & $t_{(8)}=2.67$ & $0.02^{*}$ \\
\hline Input resistance (M $\Omega$ ) & $736.7 \pm 456$ & $830.8 \pm 588$ & $t_{(6)}=1.4$ & 0.1 & $955.6 \pm 1057$ & $1110 \pm 918$ & $W=31$ & 0.07 \\
\hline Rheobase current (pA) & $29.4 \pm 18$ & $27.1 \pm 15$ & $t_{(6)}=1.3$ & 0.2 & $24.3 \pm 15$ & $18.2 \pm 12$ & $t_{(8)}=2.5$ & $0.03^{*}$ \\
\hline Voltage threshold (mV) & $-33.5 \pm 4$ & $-37.7 \pm 6$ & $t_{(6)}=1.4$ & 0.2 & $-37.1 \pm 5$ & $-36.7 \pm 3$ & $t_{(8)}=0.4$ & 0.6 \\
\hline Spontaneous firing frequency $(\mathrm{Hz})$ & $0.08 \pm 0.15$ & $0.11 \pm 0.18$ & $W=6$ & 0.3 & $0.12 \pm 0.26$ & $0.25 \pm 0.36$ & $W=22$ & 0.07 \\
\hline
\end{tabular}

${ }^{a}$ For comparison of Shox2 in properties from uninjured and SCI mice in ACSF and the 5- $\mathrm{HT}_{2 \mathrm{~A}}$ receptor antagonist (ketanserin), see Extended Data Table 7-1.

* Statistical significance: $p<0.05$

Table 8. Effects of 5-HT receptor activation on Shox2 in properties ${ }^{a}$

\begin{tabular}{|c|c|c|c|c|c|c|c|c|c|}
\hline & & \multicolumn{3}{|l|}{ Uninjured } & \multicolumn{3}{|l|}{$\mathrm{SCl}$} & \multicolumn{2}{|c|}{ Uninjured vs SCl } \\
\hline & & mean $\pm S D$ & test & $p$ & mean $\pm S D$ & test & $p$ & test & $p$ \\
\hline \multirow[t]{2}{*}{$5-\mathrm{HT}_{7}$ receptor activation } & $\mathrm{E}_{\mathrm{m},} \Delta$ from antagonist & $3.6 \pm 3$ & $t_{(7)}=3.2$ & $0.01^{*}$ & $3.5 \pm 4$ & $t_{(11)}=2.9$ & $0.01^{*}$ & $t_{(18)}=0.02$ & 0.9 \\
\hline & Firing frequency at $1.5 \times$ rheobase ( $\%$ of antagonist) & $119.2 \pm 44$ & $W=9$ & 0.4 & $101.1 \pm 39$ & $W=-5$ & 0.9 & $U=24$ & 0.3 \\
\hline \multirow[t]{2}{*}{$5-\mathrm{HT}_{2 \mathrm{~A}}$ receptor activation } & $\mathrm{E}_{\mathrm{m},} \Delta$ from antagonist & $0.6 \pm 3$ & $W=-2$ & 0.9 & $0.4 \pm 2$ & $t_{(9)}=0.5$ & 0.6 & $U=33$ & 0.5 \\
\hline & Rheobase current (\% of antagonist) & $98.4 \pm 29$ & $t_{(7)}=0.1$ & 0.8 & $91.4 \pm 26$ & $W=-14$ & 0.2 & $U=33.5$ & 0.5 \\
\hline \multirow{2}{*}{ 5- $\mathrm{HT}_{2 \mathrm{~B} / 2 \mathrm{C}}$ receptor activation } & Rheobase current (\% of antagonist) & $92.1 \pm 19$ & $t_{(6)}=1.0$ & 0.3 & $73.2 \pm 17$ & $t_{(8)}=4.1$ & $0.003^{*}$ & $t_{(14)}=1.7$ & 0.1 \\
\hline & Firing frequency at $1.5 \times$ rheobase (\% of antagonist) & $99.3 \pm 9$ & $W=-1$ & 0.9 & $106.9 \pm 22$ & $t_{(7)}=0.8$ & 0.4 & $U=20$ & 0.6 \\
\hline
\end{tabular}

${ }^{a}$ Uninjured and SCl, one-sample $t$ test or Wilcoxon signed rank test (W); Uninjured versus SCl, unpaired $t$ test or Mann-Whitney $U$ test.

*Statistical significance: $p<0.05$. 
A Uninjured

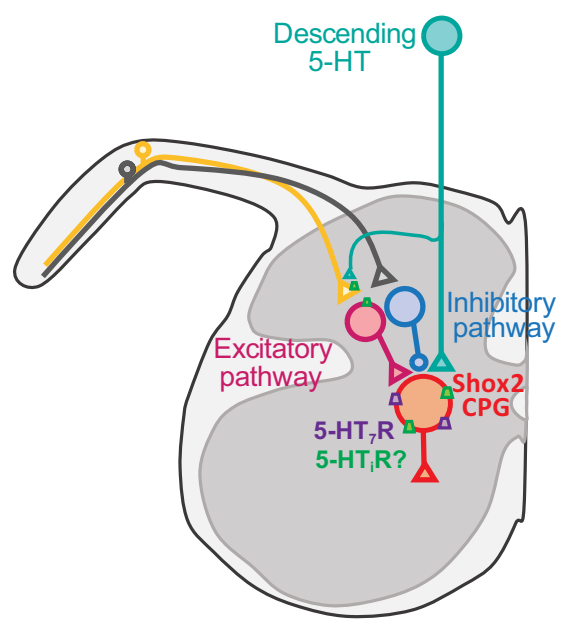

B

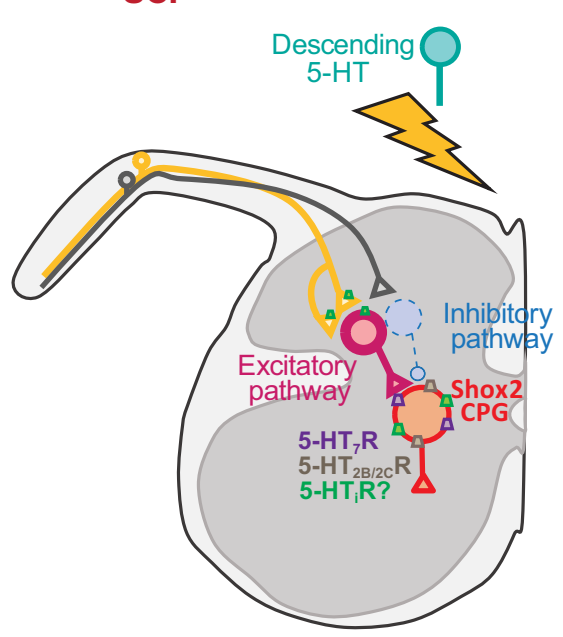

Figure 9. Hypothesized SCl-induced plasticity of sensory afferent transmission to and serotonergic modulation of Shox2 INs. A, In uninjured mice, sensory afferent transmission to Shox2 INs is mediated by both inhibitory and excitatory pathways. 5-HT modulates Shox2 INs at a presynaptic level by the activation of inhibitory $5-\mathrm{HT}$ receptors $\left(5-\mathrm{HT}_{\mathrm{i}}\right.$, i.e., $\left.5-\mathrm{HT}_{1}\right)$ on the terminals of the afferent fibers and/or interposed excitatory INs. 5-HT also modulates Shox2 INs at a postsynaptic level by activating both inhibitory (i.e., $5-\mathrm{HT}_{1}$, green rectangles) and excitatory $5-\mathrm{HT}_{7}$ receptors (purple rectangles). $\boldsymbol{B}$, After $\mathrm{SCl}$, the predominant afferent transmission pathway is excitatory, possibly because of an increased excitability of excitatory INs (pink) interposed between primary afferents and Shox2 INs and/or a reduction in the excitability in inhibitory INs (blue) interposed between primary afferents and Shox2 INs and/or changes in the afferent fiber projections to interposed INs. 5-HT modulation of excitatory afferent pathways to Shox2 INs does not change; however, the postsynaptic modulation of Shox2 INs is mainly excitatory due to $5-\mathrm{HT}_{7}$ receptors and an increase in $5-\mathrm{HT}_{2 \mathrm{~B} / 2 \mathrm{C}}$ receptor expression. Presynaptic modulation from inhibitory 5 - $\mathrm{HT}$ receptors remains on $\mathrm{SCl}$; however, it remains uncertain if the expression on Shox2 INs is altered.

which partly overlap with the Shox 2 IN population. Shox $2^{+}$ nonV2a INs are implicated in locomotor rhythm generation, and Shox $2^{+}$V2a INs are likely premotor INs (Dougherty et al., 2013). Although we did not distinguish between Shox $2^{+}$nonV2a INs and Shox $2^{+}$V2a INs, we observed oscillations in $23 \%$ of Shox 2 INs and similar oscillations were observed in V2a INs only in the presence of 5-HT (Husch et al., 2015). Although similar firing properties were observed in V2a INs (Husch et al., 2015) and Shox2 INs, delay and initial burst firing were more prevalent in Shox2 INs. In addition to spontaneous oscillations, Shox 2 INs share other properties displayed by CPG neurons, including sensory afferent input and 5-HT modulation (Brownstone and Wilson, 2008; Dougherty and $\mathrm{Ha}$, 2019). Together, this suggests that, as in the neonatal preparation, adult Shox2 INs are part of CPG and may serve multiple roles.

\section{Cell-specific SCI-induced plasticity}

Most SCI-induced plasticity studies have focused on motor neurons or unidentified INs (Guertin, 2012; Cote et al., 2017). Shox2 INs did not display SCI-induced changes in intrinsic properties and excitability, similar to what has been shown in V2a INs (Husch et al., 2012). Shox2 IN responses to sensory afferent stimulation after SCI became predominantly excitatory, but spontaneous inhibitory inputs to Shox2 INs remained and were larger in amplitude. This suggests that the lack of evoked inhibitory responses is not because of changes in chloride homeostasis (Boulenguez et al., 2010; Lu et al., 2018). Instead, the INs interposed in inhibitory and excitatory primary afferent pathways to Shox 2 INs are affected differentially by the chronic lack of descending control. This may include afferent sprouting (Krenz and Weaver, 1998; Tan et al., 2012; Detloff et al., 2014) increasing contacts to INs mediating the excitatory pathways and/or changes in the excitability of the interposed INs, either facilitating the excitatory pathways and/or suppressing inhibitory pathways (Fig. 9). These data demonstrate that plasticity mechanisms after SCI do not occur equally in all spinal INs and support an overall conservation of CPG function acted on by altered controlling systems.

\section{Sensory afferent control of Shox2 neurons}

Shox 2 and Hb9 INs, populations of INs linked to generation of locomotor rhythm (Wilson et al., 2005; Dougherty et al., 2013; Caldeira et al., 2017), both receive low threshold sensory afferent input which can perturb drug evoked locomotion in the neonatal spinal cord (Hinckley et al., 2010; Li et al., 2019). Similar to the neonate, adult Shox2 INs receive synaptic inputs from both low (presumably group I/II/A $\beta$ ) and high threshold (presumably group III/IV/ $\mathrm{A} \delta / \mathrm{C})$ afferent fibers. The adult slice preparation limits the precise identification of afferent fiber types and restricts the testable inputs to local afferent projections so the inputs here are likely underestimated. Both monosynaptic and disynaptic excitatory pathways contact rhythm generating INs (Gossard et al., 1994; Iizuka et al., 1997; Stecina et al., 2005). Although inhibitory pathways were not suggested in cat and rat, Shox2 INs in neonatal mouse similarly displayed excitatory, inhibitory, and mixed (both excitatory and inhibitory) responses to dorsal root stimulation (Li et al., 2019), suggesting polysynaptic pathways with excitatory and inhibitory INs interposed.

Sensory afferent transmission to spinal neurons is sophisticatedly modulated depending on circumstance and changes dynamically during locomotion (Gossard, 1996; Rudomin and Schmidt, 1999; Rossignol et al., 2006; Hultborn and Nielsen, 2007). One mechanism to control afferent synaptic transmission is through serotonergic inhibitory actions on the terminals of afferent fibers or INs (Wallis et al., 1993; Lopez-Garcia and King, 1996; Jankowska et al., 2000; Dougherty et al., 2005; Garcia-Ramirez et al., 2014). Surprisingly, we found that 5-HT selectively modulates afferent transmission to Shox2 INs, depressing excitatory pathways but having no significant effect on inhibitory pathways. This suggests an intricate 5-HT control of sensory information during locomotion.

\section{Plasticity of serotonergic control of Shox 2 INs}

5 -HT induces locomotion by acting on the locomotor CPG (Cazalets et al., 1992; Jacobs and Fornal, 1993; Madriaga et al., 2004; Jordan et al., 2008). Here, we found that $10 \mu \mathrm{m}$ 5-HT depolarizes Shox 2 INs and reduces the threshold for the action potential generation. However, $0.1 \mu \mathrm{M} 5$-HT produces the opposite effect in uninjured mice, hyperpolarizing Shox2 INs and decreasing the spontaneous firing frequency. This dual modulation suggests the participation of different 5-HT receptor subtypes with opposing actions, as occurs in motor neurons involving $5-\mathrm{HT}_{1 \mathrm{~A}}$ and $5-\mathrm{HT}_{2}$ receptors (Cotel et al., 2013). Here, we found that activation of $5-\mathrm{HT}_{7}$ receptors, but not $5-\mathrm{HT}_{2}$ receptors, results in 
excitatory actions on Shox 2 INs in uninjured mice. The receptors mediating the inhibitory actions at low 5-HT concentrations remain to be determined, but the $5-\mathrm{HT}_{1 \mathrm{~A}}$ receptors are a likely candidate (Beato and Nistri, 1998; Cotel et al., 2013).

It is also possible that diverse receptors lead to differential modulation of Shox 2 IN subpopulations. Indeed, V2a INs, which include Shox $2^{+}$V2a INs, display excitatory responses to 5-HT (Husch et al., 2012); however, a reduction in the excitability of V2a INs in low 5-HT concentrations was not reported. Thus, the possibility of subpopulation-dependent modulatory properties, particularly with regard to inhibitory modulation by $5-\mathrm{HT}$, is still open. Differential 5-HT modulatory actions on Shox2 IN subpopulations would provide one way for cell type-specific control and gating during locomotion.

We found that there is a heightened excitatory response of Shox2 INs to 5-HT after SCI, and our results suggest that this is mediated mainly by $5-\mathrm{HT}_{2 \mathrm{~B} / 2 \mathrm{C}}$ receptors. Activation of $5-\mathrm{HT}_{7}$ receptors increases the excitability of Shox2 INs from both uninjured and SCI mice, but activation of $5-\mathrm{HT}_{2 \mathrm{~B} / \mathrm{C}}$ receptors only leads to significant effect after SCI. These findings reveal plasticity at the level of 5-HT receptors on Shox 2 INs. Similar 5-HT supersensitivity effects have been demonstrated in motor neurons (Kong et al., 2010; Murray et al., 2010), V2a INs (Husch et al., 2012), and unidentified dorsal horn and intermediate zone INs (Ren et al., 2013), were an upregulation in the expression of $5-\mathrm{HT}_{2 \mathrm{~A}}$ and/or $5-\mathrm{HT}_{2 \mathrm{C}}$ receptors after $\mathrm{SCI}$ has been demonstrated (Fuller et al., 2005; Kong et al., 2010; Murray et al., 2010; Husch et al., 2012; Navarrett et al., 2012), presumably a compensatory response to the lack of descending excitatory drive. Additionally, constitutively active $5-\mathrm{HT}_{2 \mathrm{C}}$ receptors are expressed after SCI (Murray et al., 2010). The increased excitation because of the activation of $5-\mathrm{HT}_{2 \mathrm{~B} / 2 \mathrm{C}}$ receptors was in the presence of an agonist; however, the Shox2 INs from SCI mice were hyperpolarized by the $5-\mathrm{HT}_{2 \mathrm{~B} / 2 \mathrm{C}}$ antagonist (Extended Data Table 6-1), which suggests that constitutively active receptors may be expressed. The loss of the inhibitory response of Shox2 INs to 5-HT after SCI may correspond to an upregulation of $5-\mathrm{HT}_{2 \mathrm{~B} / 2 \mathrm{C}}$ receptors masking any inhibitory effects; however, we cannot rule out a possible downregulation of $5-\mathrm{HT}_{1}$ receptors and/or a reduction in 5-HT transporter (Husch et al., 2012). Interestingly, we did not find changes in the 5-HT modulation of afferent input to Shox2 INs after SCI, suggesting that the plasticity produced by the lack of 5-HT descending control is not global.

\section{Therapeutic implications}

Based on observations from patients with SCI and animal models, it has been inferred that CPG circuitry remains intact after SCI (Calancie et al., 1994; Bussel et al., 1996; Barriere et al., 2008; Guertin, 2014; Taccola et al., 2018). To circumvent the lack of descending controls, therapeutic interventions aim to access these circuits to activate and sustain locomotor control after injury. Sensory afferent activation has been a primary way to access CPG neurons in stimulation- and activity-based therapies (Edgerton et al., 2008; Courtine et al., 2009; Capogrosso et al., 2013; Cote et al., 2017). In animal models, administration of various 5-HT receptor agonists in combination with activity- or stimulation-based treatments further improves locomotor recovery (Antri et al., 2005; Guertin and Steuer, 2005; Landry et al., 2006; Musienko et al., 2011). Our results demonstrate that, after SCI, sensory afferent inputs and descending control (5-HT modulation) change to prioritize the excitation of Shox2 INs. This is likely adaptive and facilitates CPG activation. Future strategies will need to balance the promotion of these beneficial changes while restoring inhibition at these access points to regain control of the CPG and restore locomotor function.

\section{References}

Akay T, Tourtellotte WG, Arber S, Jessell TM (2014) Degradation of mouse locomotor pattern in the absence of proprioceptive sensory feedback. Proc Natl Acad Sci USA 111:16877-16882.

Antri M, Barthe JY, Mouffle C, Orsal D (2005) Long-lasting recovery of locomotor function in chronic spinal rat following chronic combined pharmacological stimulation of serotonergic receptors with 8-OHDPAT and quipazine. Neurosci Lett 384:162-167.

Bandaru SP, Liu S, Waxman SG, Tan AM (2015) Dendritic spine dysgenesis contributes to hyperreflexia after spinal cord injury. J Neurophysiol 113:1598-1615.

Barriere G, Leblond H, Provencher J, Rossignol S (2008) Prominent role of the spinal central pattern generator in the recovery of locomotion after partial spinal cord injuries. J Neurosci 28:3976-3987.

Beato M, Nistri A (1998) Serotonin-induced inhibition of locomotor rhythm of the rat isolated spinal cord is mediated by the 5-HT1 receptor class. Proc Biol Sci 265:2073-2080.

Bellardita C, Caggiano V, Leiras R, Caldeira V, Fuchs A, Bouvier J, Low P, Kiehn O (2017) Spatiotemporal correlation of spinal network dynamics underlying spasms in chronic spinalized mice. Elife 6:e23011.

Bennett DJ, Li Y, Siu M (2001a) Plateau potentials in sacrocaudal motoneurons of chronic spinal rats, recorded in vitro. J Neurophysiol 86:19551971.

Bennett DJ, Li Y, Harvey PJ, Gorassini M (2001b) Evidence for plateau potentials in tail motoneurons of awake chronic spinal rats with spasticity. J Neurophysiol 86:1972-1982.

Boulenguez P, Liabeuf S, Bos R, Bras H, Jean-Xavier C, Brocard C, Stil A, Darbon P, Cattaert D, Delpire E, Marsala M, Vinay L (2010) Down-regulation of the potassium-chloride cotransporter KCC2 contributes to spasticity after spinal cord injury. Nat Med 16:302-307.

Bouyer LJ, Rossignol S (2003) Contribution of cutaneous inputs from the hindpaw to the control of locomotion: II. Spinal cats. J Neurophysiol 90:3640-3653.

Britz O, Zhang J, Grossmann KS, Dyck J, Kim JC, Dymecki S, Gosgnach S, Goulding M (2015) A genetically defined asymmetry underlies the inhibitory control of flexor-extensor locomotor movements. Elife 4:e04718.

Brownstone RM, Wilson JM (2008) Strategies for delineating spinal locomotor rhythm-generating networks and the possible role of $\mathrm{Hb} 9$ interneurones in rhythmogenesis. Brain Res Rev 57:64-76.

Bui TV, Stifani N, Akay T, Brownstone RM (2016) Spinal microcircuits comprising dI3 interneurons are necessary for motor functional recovery following spinal cord transection. Elife 5:e21715.

Bussel B, Roby-Brami A, Azouvi P, Biraben A, Yakovleff A, Held JP (1988) Myoclonus in a patient with spinal cord transection: possible involvement of the spinal stepping generator. Brain 111:1235-1245.

Bussel B, Roby-Brami A, Néris OR, Yakovleff A (1996) Evidence for a spinal stepping generator in man. Paraplegia 34:91-92.

Cabaj AM, Majczyński H, Couto E, Gardiner PF, Stecina K, Sławińska U, Jordan LM (2017) Serotonin controls initiation of locomotion and afferent modulation of coordination via 5-HT7 receptors in adult rats. J Physiol 595:301-320.

Calancie B, Needham-Shropshire B, Jacobs P, Willer K, Zych G, Green BA (1994) Involuntary stepping after chronic spinal cord injury: evidence for a central rhythm generator for locomotion in man. Brain 117:1143-1159.

Caldeira V, Dougherty KJ, Borgius L, Kiehn O (2017) Spinal Hb9::Crederived excitatory interneurons contribute to rhythm generation in the mouse. Sci Rep 7:41369.

Capogrosso M, Wenger N, Raspopovic S, Musienko P, Beauparlant J, Bassi Luciani L, Courtine G, Micera S (2013) A computational model for epidural electrical stimulation of spinal sensorimotor circuits. J Neurosci 33:19326-19340.

Cazalets JR, Sqalli-Houssaini Y, Clarac F (1992) Activation of the central pattern generators for locomotion by serotonin and excitatory amino acids in neonatal rat. J Physiol 455:187-204.

Cote MP, Murray M, Lemay MA (2017) Rehabilitation strategies after spinal cord injury: inquiry into the mechanisms of success and failure. J Neurotrauma 34:1841-1857. 
Cotel F, Exley R, Cragg SJ, Perrier JF (2013) Serotonin spillover onto the axon initial segment of motoneurons induces central fatigue by inhibiting action potential initiation. Proc Natl Acad Sci USA 110:4774-4779.

Courtine G, Gerasimenko Y, van den Brand R, Yew A, Musienko P, Zhong H, Song B, Ao Y, Ichiyama RM, Lavrov I, Roy RR, Sofroniew MV, Edgerton VR (2009) Transformation of nonfunctional spinal circuits into functional states after the loss of brain input. Nat Neurosci 12:1333-1342.

Dai Y, Carlin KP, Li Z, McMahon DG, Brownstone RM, Jordan LM (2009) Electrophysiological and pharmacological properties of locomotor activity-related neurons in cfos-EGFP mice. J Neurophysiol 102:3365-3383.

D'Amico JM, Li Y, Bennett DJ, Gorassini MA (2013) Reduction of spinal sensory transmission by facilitation of 5-HT1B/D receptors in noninjured and spinal cord-injured humans. J Neurophysiol 109:1485-1493.

Detloff MR, Smith EJ, Quiros Molina D, Ganzer PD, Houlé JD (2014) Acute exercise prevents the development of neuropathic pain and the sprouting of non-peptidergic (GDNF- and artemin-responsive) c-fibers after spinal cord injury. Exp Neurol 255:38-48.

Dougherty KJ, Ha NT (2019) The rhythm section: an update on spinal interneurons setting the beat for mammalian locomotion. Curr Opin Physiol 8:84-93.

Dougherty KJ, Hochman S (2008) Spinal cord injury causes plasticity in a subpopulation of lamina I GABAergic interneurons. J Neurophysiol 100:212-223.

Dougherty KJ, Bannatyne BA, Jankowska E, Krutki P, Maxwell DJ (2005) Membrane receptors involved in modulation of responses of spinal dorsal horn interneurons evoked by feline group II muscle afferents. J Neurosci 25:584-593.

Dougherty KJ, Zagoraiou L, Satoh D, Rozani I, Doobar S, Arber S, Jessell TM, Kiehn O (2013) Locomotor rhythm generation linked to the output of spinal shox2 excitatory interneurons. Neuron 80:920-933.

Dunbar MJ, Tran MA, Whelan PJ (2010) Endogenous extracellular serotonin modulates the spinal locomotor network of the neonatal mouse. J Physiol 588:139-156.

Duru PO, Tillakaratne NJ, Kim JA, Zhong H, Stauber SM, Pham TT, Xiao MS, Edgerton VR, Roy RR (2015) Spinal neuronal activation during locomotor-like activity enabled by epidural stimulation and 5-hydroxytryptamine agonists in spinal rats. J Neurosci Res 93:1229-1239.

Edgerton VR, Tillakaratne NJ, Bigbee AJ, de Leon RD, Roy RR (2004) Plasticity of the spinal neural circuitry after injury. Annu Rev Neurosci 27:145-167.

Edgerton VR, Courtine G, Gerasimenko YP, Lavrov I, Ichiyama RM, Fong AJ, Cai LL, Otoshi CK, Tillakaratne NJ, Burdick JW, Roy RR (2008) Training locomotor networks. Brain Res Rev 57:241-254.

Falgairolle M, O'Donovan MJ (2019) V1 interneurons regulate the pattern and frequency of locomotor-like activity in the neonatal mouse spinal cord. PLoS Biol 17:e3000447.

Formento E, Minassian K, Wagner F, Mignardot JB, Le Goff-Mignardot CG, Rowald A, Bloch J, Micera S, Capogrosso M, Courtine G (2018) Electrical spinal cord stimulation must preserve proprioception to enable locomotion in humans with spinal cord injury. Nat Neurosci 21:1728-1741.

Fouad K, Rank MM, Vavrek R, Murray KC, Sanelli L, Bennett DJ (2010) Locomotion after spinal cord injury depends on constitutive activity in serotonin receptors. J Neurophysiol 104:2975-2984

Fuller DD, Baker-Herman TL, Golder FJ, Doperalski NJ, Watters JJ, Mitchell GS (2005) Cervical spinal cord injury upregulates ventral spinal 5-HT2A receptors. J Neurotrauma 22:203-213.

Garcia-Ramirez DL, Calvo JR, Hochman S, Quevedo JN (2014) Serotonin, dopamine and noradrenaline adjust actions of myelinated afferents via modulation of presynaptic inhibition in the mouse spinal cord. PLoS One 9:e89999.

Gerasimenko YP, Ichiyama RM, Lavrov IA, Courtine G, Cai L, Zhong H, Roy RR, Edgerton VR (2007) Epidural spinal cord stimulation plus quipazine administration enable stepping in complete spinal adult rats. J Neurophysiol 98:2525-2536.

Gossard JP (1996) Control of transmission in muscle group IA afferents during fictive locomotion in the cat. J Neurophysiol 76:4104-4112.

Gossard JP, Brownstone RM, Barajon I, Hultborn H (1994) Transmission in a locomotor-related group Ib pathway from hindlimb extensor muscles in the cat. Exp Brain Res 98:213-228.

Goulding M (2009) Circuits controlling vertebrate locomotion: moving in a new direction. Nat Rev Neurosci 10:507-518.
Graham Brown TG (1911) The intrinsic factors in the act of progression in the mammal. Proc R Soc Lond B 308-319.

Guertin PA (2009) Recovery of locomotor function with combinatory drug treatments designed to synergistically activate specific neuronal networks. Curr Med Chem 16:1366-1371.

Guertin PA (2012) Central pattern generator for locomotion: anatomical, physiological, and pathophysiological considerations. Front Neurol 3:183.

Guertin PA (2014) Preclinical evidence supporting the clinical development of central pattern generator-modulating therapies for chronic spinal cord-injured patients. Front Hum Neurosci 8:272.

Guertin PA, Steuer I (2005) Ionotropic 5-HT3 receptor agonist-induced motor responses in the hindlimbs of paraplegic mice. J Neurophysiol 94:3397-3405

Ha NT, Dougherty KJ (2018) Spinal Shox2 interneuron interconnectivity related to function and development. Elife 7:e42519.

Hasegawa Y, Ono H (1996) Effects of 8-OH-DPAT, a 5-HT1A receptor agonist, and DOI, a 5-HT2A/2C agonist, on monosynaptic transmission in spinalized rats. Brain Res 738:158-161

Hinckley CA, Wiesner EP, Mentis GZ, Titus DJ, Ziskind-Conhaim L (2010) Sensory modulation of locomotor-like membrane oscillations in Hb9expressing interneurons. J Neurophysiol 103:3407-3423.

Hochman S, Garraway S, Machacek D, Shay B (2001) 5-HT receptors and the neuromodulatory control of spinal cord function. In: Motor neurobiology of the spinal cord (Cope TC, ed), pp 47-87. Boca Raton, FL: CRC.

Honda M, Imaida K, Tanabe M, Ono H (2004) Endogenously released 5-hydroxytryptamine depresses the spinal monosynaptic reflex via 5-HT1D receptors. Eur J Pharmacol 503:55-61.

Hounsgaard J, Kiehn O (1989) Serotonin-induced bistability of turtle motoneurones caused by a nifedipine-sensitive calcium plateau potential. J Physiol 414:265-282.

Hultborn H, Nielsen JB (2007) Spinal control of locomotion: from cat to man. Acta Physiol 189:111-121.

Husch A, Van Patten GN, Hong DN, Scaperotti MM, Cramer N, HarrisWarrick RM (2012) Spinal cord injury induces serotonin supersensitivity without increasing intrinsic excitability of mouse V2a interneurons. J Neurosci 32:13145-13154.

Husch A, Dietz SB, Hong DN, Harris-Warrick RM (2015) Adult spinal V2a interneurons show increased excitability and serotonin-dependent bistability. J Neurophysiol 113:1124-1134.

Ichiyama RM, Gerasimenko Y, Jindrich DL, Zhong H, Roy RR, Edgerton VR (2008) Dose dependence of the 5-HT agonist quipazine in facilitating spinal stepping in the rat with epidural stimulation. Neurosci Lett 438:281285.

Iizuka M, Kiehn O, Kudo N (1997) Development in neonatal rats of the sensory resetting of the locomotor rhythm induced by NMDA and 5-HT. Exp Brain Res 114:193-204.

Jacobs BL, Fornal CA (1993) 5-HT and motor control: a hypothesis. Trends Neurosci 16:346-352.

Jankowska E, Hammar I, Chojnicka B, Heden CH (2000) Effects of monoamines on interneurons in four spinal reflex pathways from group I and/ or group II muscle afferents. Eur J Neurosci 12:701-714.

Jordan LM, Liu J, Hedlund PB, Akay T, Pearson KG (2008) Descending command systems for the initiation of locomotion in mammals. Brain Res Rev 57:183-191.

Kao T, Shumsky JS, Jacob-Vadakot S, Himes BT, Murray M, Moxon KA (2006) Role of the 5-HT2C receptor in improving weight-supported stepping in adult rats spinalized as neonates. Brain Res 1112:159-168.

Kiehn O (2016) Decoding the organization of spinal circuits that control locomotion. Nat Rev Neurosci 17:224-238.

Kim D, Murray M, Simansky KJ (2001) The serotonergic 5-HT(2C) agonist $\mathrm{m}$-chlorophenylpiperazine increases weight-supported locomotion without development of tolerance in rats with spinal transections. Exp Neurol 169:496-500.

Kjaerulff O, Kiehn O (1996) Distribution of networks generating and coordinating locomotor activity in the neonatal rat spinal cord in vitro: a lesion study. J Neurosci 16:5777-5794.

Kong XY, Wienecke J, Hultborn H, Zhang M (2010) Robust upregulation of serotonin $2 \mathrm{~A}$ receptors after chronic spinal transection of rats: an immunohistochemical study. Brain Res 1320:60-68. 
Kremer E, Lev-Tov A (1997) Localization of the spinal network associated with generation of hindlimb locomotion in the neonatal rat and organization of its transverse coupling system. J Neurophysiol 77:1155-1170.

Krenz NR, Weaver LC (1998) Sprouting of primary afferent fibers after spinal cord transection in the rat. Neuroscience 85:443-458.

Landry ES, Guertin PA (2004) Differential effects of 5-HT1 and 5-HT2 receptor agonists on hindlimb movements in paraplegic mice. Prog Neuropsychopharmacol Biol Psychiatry 28:1053-1060.

Landry ES, Lapointe NP, Rouillard C, Levesque D, Hedlund PB, Guertin PA (2006) Contribution of spinal 5-HT1A and 5-HT7 receptors to locomotor-like movement induced by 8 -OH-DPAT in spinal cord-transected mice. Eur J Neurosci 24:535-546.

Lee JK, Johnson CS, Wrathall JR (2007) Up-regulation of 5-HT2 receptors is involved in the increased $\mathrm{H}$-reflex amplitude after contusive spinal cord injury. Exp Neurol 203:502-511.

Li EZ, Garcia-Ramirez DL, Dougherty KJ (2019) Flexor and extensor ankle afferents broadly innervate locomotor spinal Shox2 neurons and induce similar effects in neonatal mice. Front Cell Neurosci 13:452.

Lin S, Li Y, Lucas-Osma AM, Hari K, Stephens MJ, Singla R, Heckman CJ, Zhang Y, Fouad K, Fenrich KK, Bennett DJ (2019) Locomotor-related $\mathrm{V} 3$ interneurons initiate and coordinate muscles spasms after spinal cord injury. J Neurophysiol 121:1352-1367.

Liu J, Jordan LM (2005) Stimulation of the parapyramidal region of the neonatal rat brain stem produces locomotor-like activity involving spinal 5HT7 and 5-HT2A receptors. J Neurophysiol 94:1392-1404.

Liu J, Akay T, Hedlund PB, Pearson KG, Jordan LM (2009) Spinal 5-HT7 receptors are critical for alternating activity during locomotion: in vitro neonatal and in vivo adult studies using 5-HT7 receptor knockout mice. J Neurophysiol 102:337-348.

Lopez-Garcia JA, King AE (1996) Pre- and post-synaptic actions of 5-hydroxytryptamine in the rat lumbar dorsal horn in vitro: implications for somatosensory transmission. Eur J Neurosci 8:2188-2197.

Lu Y, Doroshenko M, Lauzadis J, Kanjiya MP, Rebecchi MJ, Kaczocha M, Puopolo M (2018) Presynaptic inhibition of primary nociceptive signals to dorsal horn lamina I neurons by dopamine. J Neurosci 38:8809-8821.

Lu Y, Zheng J, Xiong L, Zimmermann M, Yang J (2008) Spinal cord injuryinduced attenuation of GABAergic inhibition in spinal dorsal horn circuits is associated with down-regulation of the chloride transporter KCC2 in rat. J Physiol 586:5701-5715.

MacLean JN, Hochman S, Magnuson DS (1995) Lamina VII neurons are rhythmically active during locomotor-like activity in the neonatal rat spinal cord. Neurosci Lett 197:9-12.

Madisen L, Zwingman TA, Sunkin SM, Oh SW, Zariwala HA, Gu H, Ng LL, Palmiter RD, Hawrylycz MJ, Jones AR, Lein ES, Zeng H (2010) A robust and high-throughput Cre reporting and characterization system for the whole mouse brain. Nat Neurosci 13:133-140.

Madriaga MA, McPhee LC, Chersa T, Christie KJ, Whelan PJ (2004) Modulation of locomotor activity by multiple 5-HT and dopaminergic receptor subtypes in the neonatal mouse spinal cord. J Neurophysiol 92:1566-1576

Majczyński H, Cabaj AM, Jordan LM, Sławińska U (2020) Contribution of 5HT2 receptors to the control of the spinal locomotor system in intact rats. Front Neural Circuits 14:14.

McCrea DA (2001) Spinal circuitry of sensorimotor control of locomotion. J Physiol 533:41-50.

Murray KC, Nakae A, Stephens MJ, Rank M, D’Amico J, Harvey PJ, Li X, Harris RL, Ballou EW, Anelli R, Heckman CJ, Mashimo T, Vavrek R, Sanelli L, Gorassini MA, Bennett DJ, Fouad K (2010) Recovery of motoneuron and locomotor function after spinal cord injury depends on constitutive activity in 5-HT2C receptors. Nat Med 16:694-700.

Musienko P, van den Brand R, Marzendorfer O, Roy RR, Gerasimenko Y, Edgerton VR, Courtine G (2011) Controlling specific locomotor behaviors through multidimensional monoaminergic modulation of spinal circuitries. J Neurosci 31:9264-9278.

Navarrett S, Collier L, Cardozo C, Dracheva S (2012) Alterations of serotonin $2 \mathrm{C}$ and $2 \mathrm{~A}$ receptors in response to $\mathrm{T} 10$ spinal cord transection in rats. Neurosci Lett 506:74-78.

Noga BR, Johnson DM, Riesgo MI, Pinzon A (2009) Locomotor-activated neurons of the cat: I. Serotonergic innervation and co-localization of 5HT7, 5-HT2A, and 5-HT1A receptors in the thoraco-lumbar spinal cord. J Neurophysiol 102:1560-1576.
Oueghlani Z, Juvin L, Lambert FM, Cardoit L, Courtand G, Masmejean F, Cazalets JR, Barriere G (2020) Serotonergic modulation of sacral dorsal root stimulation-induced locomotor output in newborn rat. Neuropharmacology 170:107815.

Pearlstein E, Ben Mabrouk F, Pflieger JF, Vinay L (2005) Serotonin refines the locomotor-related alternations in the in vitro neonatal rat spinal cord. Eur J Neurosci 21:1338-1346.

Pearson KG (2008) Role of sensory feedback in the control of stance duration in walking cats. Brain Res Rev 57:222-227.

Rank MM, Flynn JR, Battistuzzo CR, Galea MP, Callister R, Callister RJ (2015) Functional changes in deep dorsal horn interneurons following spinal cord injury are enhanced with different durations of exercise training. J Physiol 593:331-345.

Ren LQ, Wienecke J, Chen M, Moller M, Hultborn H, Zhang M (2013) The time course of serotonin $2 \mathrm{C}$ receptor expression after spinal transection of rats: an immunohistochemical study. Neuroscience 236:31-46.

Rossignol S, Barriere G, Frigon A, Barthelemy D, Bouyer L, Provencher J, Leblond H, Bernard G (2008) Plasticity of locomotor sensorimotor interactions after peripheral and/or spinal lesions. Brain Res Rev 57:228-240.

Rossignol S, Frigon A (2011) Recovery of locomotion after spinal cord injury: some facts and mechanisms. Annu Rev Neurosci 34:413-440.

Rossignol S, Dubuc R, Gossard JP (2006) Dynamic sensorimotor interactions in locomotion. Physiol Rev 86:89-154.

Rudomin P, Schmidt RF (1999) Presynaptic inhibition in the vertebrate spinal cord revisited. Exp Brain Res 129:1-37.

Shay BL, Sawchuk M, Machacek DW, Hochman S (2005) Serotonin 5-HT2 receptors induce a long-lasting facilitation of spinal reflexes independent of ionotropic receptor activity. J Neurophysiol 94:2867-2877.

Slawinska U, Miazga K, Jordan LM (2014) 5-HT(2) and 5-HT(7) receptor agonists facilitate plantar stepping in chronic spinal rats through actions on different populations of spinal neurons. Front Neural Circuits 8:95.

Stecina K, Quevedo J, McCrea DA (2005) Parallel reflex pathways from flexor muscle afferents evoking resetting and flexion enhancement during fictive locomotion and scratch in the cat. J Physiol 569:275-290.

Taccola G, Sayenko D, Gad P, Gerasimenko Y, Edgerton VR (2018) And yet it moves: recovery of volitional control after spinal cord injury. Prog Neurobiol 160:64-81.

Takeoka A, Vollenweider I, Courtine G, Arber S (2014) Muscle spindle feedback directs locomotor recovery and circuit reorganization after spinal cord injury. Cell 159:1626-1639.

Talpalar AE, Bouvier J, Borgius L, Fortin G, Pierani A, Kiehn O (2013) Dualmode operation of neuronal networks involved in left-right alternation. Nature 500:85-88.

Tan AM, Chakrabarty S, Kimura H, Martin JH (2012) Selective corticospinal tract injury in the rat induces primary afferent fiber sprouting in the spinal cord and hyperreflexia. J Neurosci 32:12896-12908.

Vinay L, Jean-Xavier C (2008) Plasticity of spinal cord locomotor networks and contribution of cation-chloride cotransporters. Brain Res Rev 57: 103-110.

van den Brand R, Heutschi J, Barraud Q, DiGiovanna J, Bartholdi K, Huerlimann M, Friedli L, Vollenweider I, Moraud EM, Duis S, Dominici N, Micera S, Musienko P, Courtine G (2012) Restoring voluntary control of locomotion after paralyzing spinal cord injury. Science 336:1182-1185.

Wagner FB, Mignardot JB, Le Goff-Mignardot CG, Demesmaeker R, Komi S, Capogrosso M, Rowald A, Seáñez I, Caban M, Pirondini E, Vat M, McCracken LA, Heimgartner R, Fodor I, Watrin A, Seguin P, Paoles E, Van Den Keybus K, Eberle G, Schurch B, et al. (2018) Targeted neurotechnology restores walking in humans with spinal cord injury. Nature 563:65-71.

Wallis DI, Wu J, Wang X (1993) Descending inhibition in the neonate rat spinal cord is mediated by 5 -hydroxytryptamine. Neuropharmacology 32:73-83.

Wilson JM, Hartley R, Maxwell DJ, Todd AJ, Lieberam I, Kaltschmidt JA, Yoshida Y, Jessell TM, Brownstone RM (2005) Conditional rhythmicity of ventral spinal interneurons defined by expression of the $\mathrm{Hb} 9$ homeodomain protein. J Neurosci 25:5710-5719.

Zhang Y, Narayan S, Geiman E, Lanuza GM, Velasquez T, Shanks B, Akay T, Dyck J, Pearson K, Gosgnach S, Fan CM, Goulding M (2008) V3 spinal neurons establish a robust and balanced locomotor rhythm during walking. Neuron 60:84-96. 